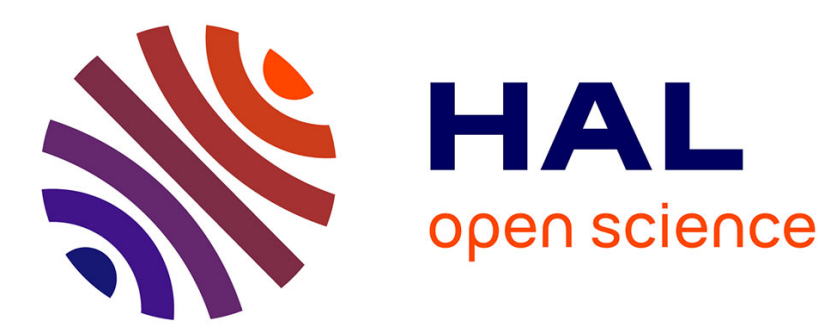

\title{
Calcium and neuronal development and growth
}

Fabienne Archer, Rachel Ashworth, Steven Bolsover

\section{To cite this version:}

Fabienne Archer, Rachel Ashworth, Steven Bolsover. Calcium and neuronal development and growth. Integrative aspects of calcium signalling, Plenum Press, 408 p., 1999, 978-1-4899-1903-8 978-1-48991901-4. hal-02840991

\section{HAL Id: hal-02840991 https://hal.inrae.fr/hal-02840991}

Submitted on 7 Jun 2020

HAL is a multi-disciplinary open access archive for the deposit and dissemination of scientific research documents, whether they are published or not. The documents may come from teaching and research institutions in France or abroad, or from public or private research centers.
L'archive ouverte pluridisciplinaire HAL, est destinée au dépôt et à la diffusion de documents scientifiques de niveau recherche, publiés ou non, émanant des établissements d'enseignement et de recherche français ou étrangers, des laboratoires publics ou privés. 


\section{Integrative Aspects of Calcium Signalling}

Edited by

Alexej Verkhratsky

Max-Delbrück Center for Molecular Medicine

Berlin, Germany

and

Emil C. Toescu

Birmingham University Medical School

Birmingham, United Kingdom

Plenum Press • New York and London 


\title{
CALCIUM AND NEURONAL DEVELOPMENT AND GROWTH
}

\author{
Fabienne Archer," Rachel Ashworth, ${ }^{*}$ and Stephen Bolsover \\ Department of Physiology \\ University College London \\ Gower Street, London WC1E 6BT, United Kingdom
}

\section{INTRODUCTION}

In the development and growth of the nervous system, as in other systems, calcium plays an important role as a second messenger within cells. Careful spatial and temporal coding allows a mechanism by which intracellular calcium concentration $\left(\left[\mathrm{Ca}^{2+}\right]_{\mathrm{i}}\right)$ integrates and delivers signals to specific effectors that act either directly and locally in the cytoplasm or within the nucleus to activate longer changes in gene regulation. Calcium has been implicated in so many aspects of nerve growth and development (including initial induction, neuronal differentiation, axogenesis and pathfinding, to synaptic transformation, formation of neural networks and neuronal survival and cell death) that it is impossible to cover all aspects within this chapter. We have concentrated on several steps in early neuronal development trying where possible to define how an ubiquitous messenger like calcium modulates many diverse processes during neuronal development and growth in a specific manner. Furthermore we have focused on the more recent advances and where relevant refer to previous reviews. Some of the aspects of later neuronal development (such as synaptic plasticity and cell death) are dealt with in accompanying chapters.

\section{CALCIUM AND EARLY NEURONAL DEVELOPMENT}

\subsection{Calcium and Neuronal Induction}

One of the most intriguing questions in development is what determines ectoderm to take a neural fate, i.e. the molecular mechanisms of neural induction. Recently, it has been

*Authors contributed jointly.

Integrative Aspects of Calcium Signalling

edited by Verkhratsky and Toescu, Plenum Press, New York, 1998

239 
shown that the bone morphogenetic proteins (BMPs) act as a signal in the ectoderm to induce an epidermal fate and thus suppress neurulation (Bang and Goulding, 1996; Mehler et al., 1997; Wilson and Hemmati-Brivanlou, 1997). Neural inducers from the organiser region have been proposed to act antagonistically to bind BMPs, thus allowing conversion of ectoderm to neuroectoderm, as shown in Figure 1. At present it is unknown whether the neural induction molecules act simply to bind BMPs or stimulate signal pathways too. Several intracellular messengers, including intracellular calcium, have been implicated as downstream effectors of neuralizing signals (reviewed by Grunz, 1997). In an amphibian system, neural induction in response to the heterologous inducer Concanavalin A did not occur when ectoderm was loaded with BAPTA-AM (Moreau et al., 1994). Furthermore, it was found that calcium influx via L-type calcium channels triggered neural induction and that noggin, a naturally occurring candidate for neural inducer, activates L-type calcium channels (Leclerc et al., 1997). Thus there is evidence that calcium is part of a signal cascade that activates neural specific gene expression at early stages of embryo development.

\subsection{Calcium and Neuronal Migration}

During normal brain development extensive neuronal migration occurs. A particularly well studied model of cell migration is the interaction of developing granule cells

A

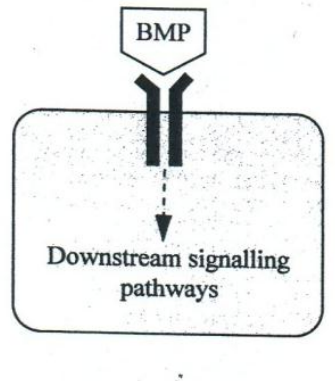

B

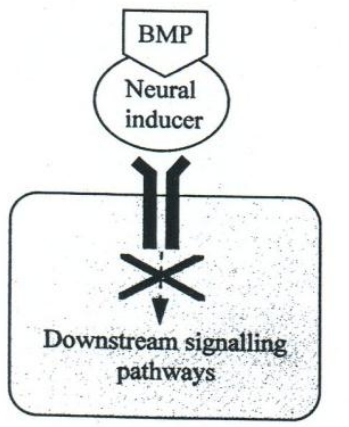

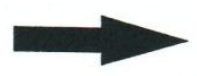

Activation of other intracellular messengers including calcium

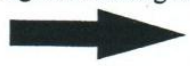

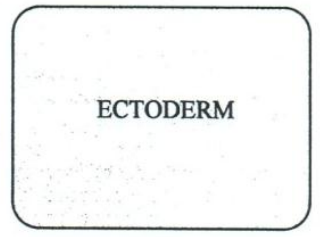

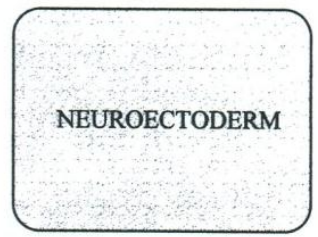

Figure 1. Diagrammatic representation of the proposed model for neuronal induction and how intracellular calcium signalling may be involved. A. Bone morphogenetic proteins (BMPs), which are expressed in the ectoderm, act as epidermal inducers. B. Neural induction molecules, e.g. chordin, noggin and follistatin, antagonise the action of BMPs at the level of the receptor and allow conversion from ectoderm to neuroectoderm. Positive downstream neuralising signals, such as calcium, may also play a role. 
with radial glial fibres as they migrate from the external granule layer across the molecular layer eventually forming a layer of granule interneurons within the mature cerebellar cortex, as represented in Figure 2 (Hatten, 1993; Rakic and Komuro, 1995). There are thought to be a combination of molecular mechanisms that enable this movement to occur including adhesion and recognition molecules, expression of neurotransmitters, receptors and ion-channels and the cytoskeleton (Rakic et al., 1994; Rakic et al., 1996). Intracellular calcium has been implicated as an important second messenger in granule cell migration. Initially it was shown that immature granule cells in cerebellar slices exhibit $\left[\mathrm{Ca}^{2+}\right]_{\mathrm{i}}$ fluctuations during their migration. Buffering $\left[\mathrm{Ca}^{2+}\right]_{i}$ with BAPTA-AM or decreasing calcium in the bathing medium reduced the rate of cell movement (Komuro and Rakic, 1993; Komuro and Rakic, 1992). Granule cell migration occurs by saltatory movement and each forward movement correlates with a $\left[\mathrm{Ca}^{2+}\right]_{i}$ peak (Komuro and Rakic, 1996). This movement has been shown to be dependent on influx of calcium via N-type calcium channels, whose expression appears to coincide with this migratory stage. NMDA receptors and possibly release from intracellular stores contribute too (Komuro and Rakic, 1996; Komuro and Rakic, 1993; Komuro and Rakic, 1992). However, studies using the weaver mutant mouse, whose granule neurons fail to migrate, show that blockade of (L-type) calcium channels rescues granule neuron outgrowth in primary cultures, so the totality of calcium's actions in this system is still far from clear (Liesi and Wright, 1996).

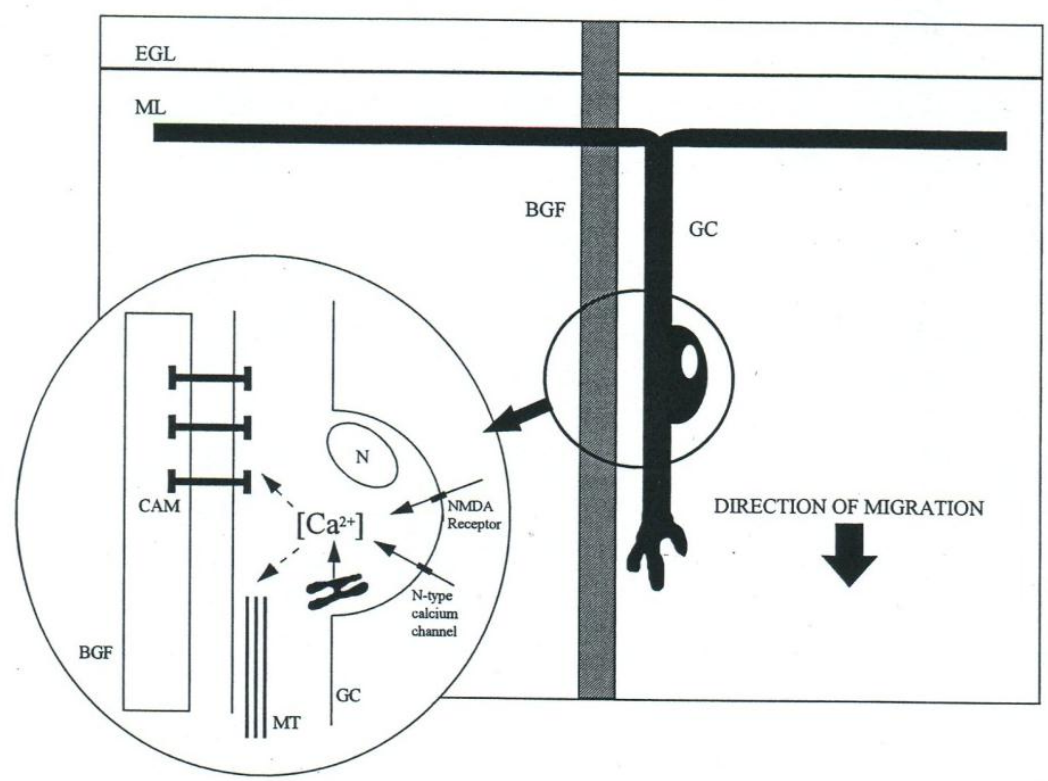

Figure 2. Migration of the cell body of a granule cell (GC) along a Bergmann glial fibre (BGF) within the molecular layer (ML) of the developing cerebellar cortex. (External germinal layer, EGL). The inset shows how intracellular calcium may be raised during neuronal migration. Dotted lines indicate possible $\left[\mathrm{Ca}^{2+}\right]_{\mathrm{i}}$ targets, including microtubules (MT) and cell adhesion molecules (CAM). (Adapted from a model by Rakic and Kumoro, 1995). 


\section{CALCIUM AND NEURONAL DIFFERENTIATION}

During development nerve cells undergo subtle and sequential changes as they differentiate to form mature neurons. There is a lot of evidence that calcium is an important second messenger in neuronal differentiation. Studies that block calcium influx or perturb intracellular calcium cause altered patterns of differentiation, including effects on gene transcription, enzyme activation, neuron transmitter phenotype, and ion channel activity and maturation, as discussed below.

\subsection{Expression of Neurotrophins}

The neurotrophin brain-derived neurotrophic factor (BDNF or NT2) has been shown to increase the survival of cortical neurons grown in culture (Ghosh et al., 1994). Influx of extracellular calcium through L-type calcium channels increased expression of BDNF in these cells and consequently promoted cell survival and outgrowth. However, activation of NMDA receptors only transiently increased BDNF expression and had no effect on cell survival indicating that the pathway of calcium entry is important in upregulation of gene expression during neuronal differentiation (discussed further in section 4.3).

\subsection{Transmitter Phenotype}

Depolarisation of neonatal rat sympathetic neurons in culture reduced synthesis of acetylcholine thus allowing adrenergic differentiation to proceed (Walicke et al., 1977). Blockade of calcium influx with various inhibitors increased acetylcholine production and reversed the developmental effect of depolarisation, suggesting that influx of calcium plays a role in determining neurotransmitter phenotype in this cell type (Walicke and Patterson, 1981). In a similar set of experiments $\mathrm{KCl}$ depolarisation of neuronal primary cultures from the spinal cord of fetal mouse increased choline acetyltransferase activity, but suppressed acetylcholinesterase activity, this effect was reversed in the presence of channel blockers and high $\mathrm{Mg}^{2+}$ suggesting that calcium influx plays a role in the development of the activity of cholinergic neurons (Ishida and Deguchi, 1983). In addition, development of GABA immunoreactivity in cultured Xenopus spinal neurons was found to require spontaneous and transient increases in $\left[\mathrm{Ca}^{2+}\right]_{i}$ via voltage-operated calcium channels (as discussed in more detail below) (Spitzer et al., 1993).

\subsection{Ion Channel Activity}

Spontaneous calcium influx is known to occur during a defined period in early development of a variety of neuronal cell types (review Spitzer, 1991) and is thought to influence calcium sensitive mechanisms that are important during this developmental stage. Spontaneous calcium activity and its effects on neuronal differentiation have been particularly well defined using amphibian spinal neurons as a model, as summarised in Figure 3 (Spitzer, 1994).

$\mathrm{Gu}$ and Spitzer (1993) propose that in embryonic Xenopus spinal neurons it is the low voltage activated (T-type) calcium current that depolarises neuronal cells activating high voltage activated (N- and L-type) calcium currents which then promote calcium influx during early development. This calcium sensitive period of development is thought to be achieved by the slow expression of $\mathrm{K}^{+}$delayed rectifier channels which play an important part in the subsequent conversion from $\mathrm{Ca}^{2+}$-dependent to $\mathrm{Na}^{+}$-dependent action po- 


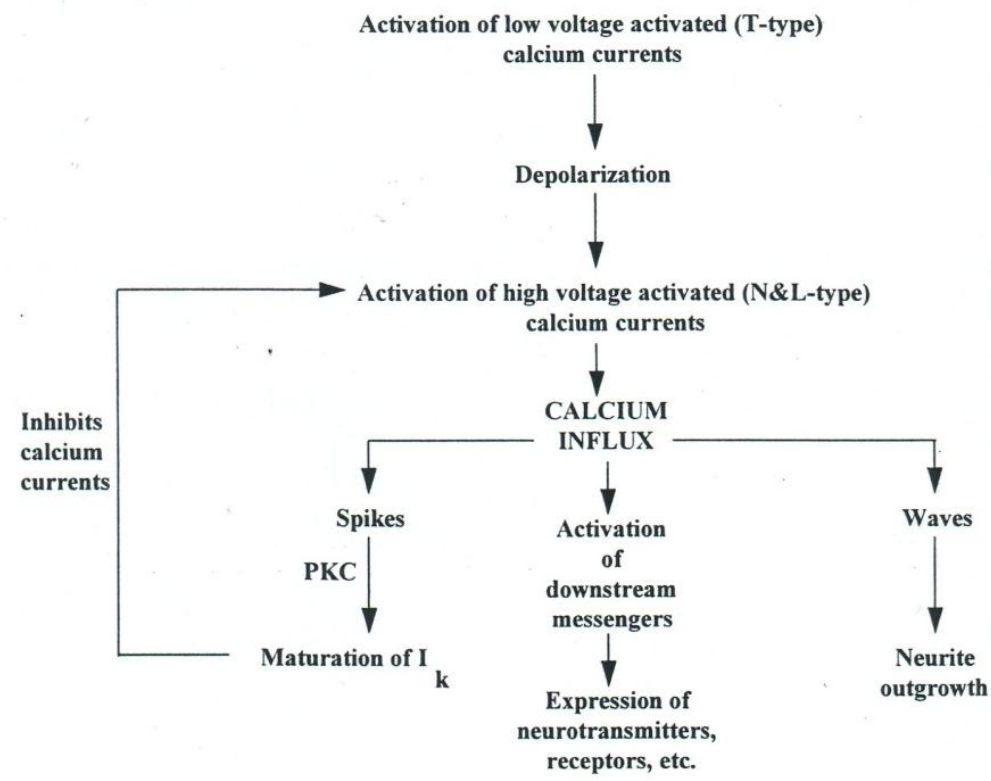

Figure 3. Schematic diagram to summarise how calcium influences early neuronal development and differentation in amphibian spinal neurons (drawn from Spitzer, 1994).

tentials during neuronal maturation both in vitro and in vivo (Desarmenien et al., 1993; Spitzer, 1991). The increase in $\left[\mathrm{Ca}^{2+}\right]_{\mathrm{i}}$ during this calcium sensitive period may feedback, possibly via PKC (Desarmenien and Spitzer, 1991), to up-regulate expression and maturation of $\mathrm{K}^{+}$delayed rectifier channel which then suppress calcium action potentials.

\subsection{Spontaneous Calcium Activity during Neuronal Differentiation}

Xenopus spinal neurons taken from the neural plate stage and grown in culture show spontaneous calcium influx: the number of cells showing $\left[\mathrm{Ca}^{2+}\right]_{\mathrm{i}}$ transients is greatest $8 \mathrm{hrs}$ after plating and falls to low levels by $15 \mathrm{hrs}$ in culture. During this early period in culture (first 4-7hrs) influx occurs via calcium channels and removal of extracellular calcium during this period is sufficient to perturb neuronal differentiation (Holliday and Spitzer, 1990). Calcium-induced calcium release from internal stores also plays a role in the neuronal differentiation at this stage of development (Holliday et al., 1991). Thus cultured Xenopus spinal neurons have a calcium sensitive period in which spontaneous influx of calcium affects normal neuronal development.

More recently the spontaneous calcium transients described above have been further characterised into two types of activity, termed "spikes" and "waves" (Gu et al., 1994). Spikes are discussed in detail here and waves are discussed further in the section on neuronal outgrowth. Calcium spikes are described as a rapid rise and fall in $\left[\mathrm{Ca}^{2+}\right]_{\mathrm{i}}$ that raise calcium throughout the entire neuron, and calcium is thought to propagate through the cell with a frequency of $2-3$ spikes/hr. Calcium spikes are proposed to be produced by 


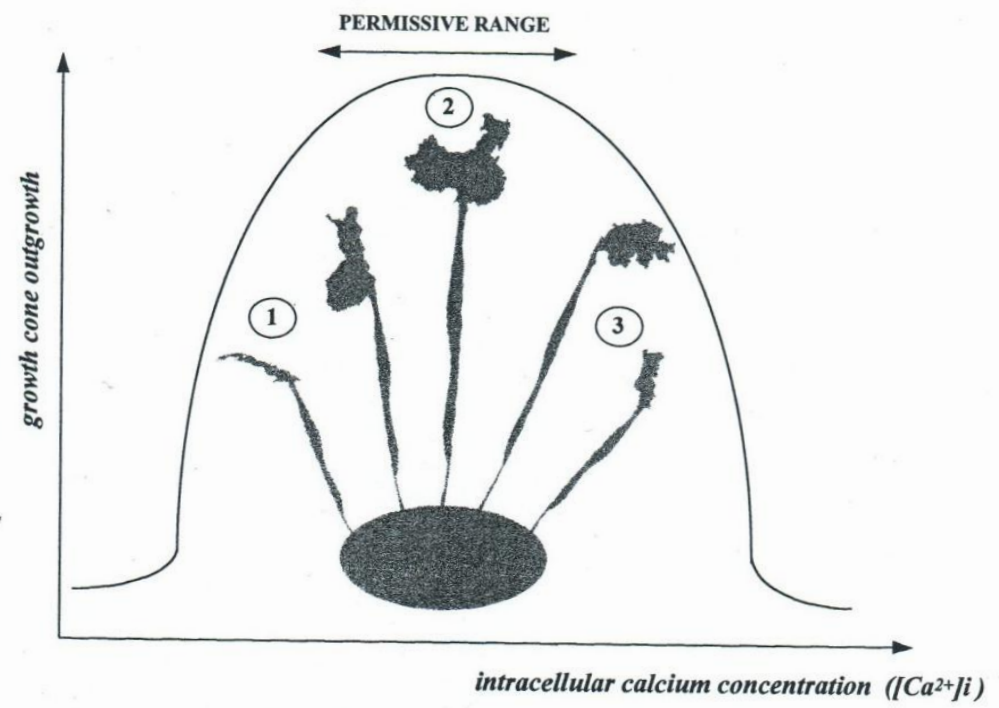

Figure 4. Schematic representation of the set-point hypothesis, adapted from Kater (1991). The growth cone motility is regulated by intracellular calcium. 1) At low calcium concentrations, (below the permissive range), the growth cone motility is reduced. 2) At the permissive range of intracellular calcium, maximal outgrowth occurs. The growth cone is well shaped with active filopodia and lamellipodia. 3) At higher calcium levels (above the permissive range), filopodia and lamellipodia ceased and neurites retract. The response of the growth cone to a stimulus inducing intracellular calcium changes will depend upon the resting calcium level of the growth cone and the amplitude of this change.

may be important in the eventual response (Fields and Nelson, 1994). The location and availability of receptors, second messenger systems, and the location and concentration of targets activated by calcium will affect how a calcium signal is processed. The equipment found in the growth cone to date are reported in Table 1.

The growth cone itself can be subdivided into distinct units of organization and the view of the growth cone as a basic unit is now seen to be an oversimplification. Rehder and Kater suggest that it is this functional compartimentalization which enables the growth cone to read the molecular terrain it traverses and to convert this information into precise motor events (Rehder et al., 1996). The growth cone is described as a central processor and the filopodia are viewed as peripheral devices with antennae-like function (Davenport et al., 1993). Signals received at a filopodium could undergo various degree of processing before being sent to the central processor unit, as illustrated in Figure 5. Calcium is proposed as being the principal second messenger able to integrate growth cone function by regulating intra- and inter-compartmental events. An environmental stimulus binds to the appropriate receptor or opens appropriate channels in the filopodial membrane causing a local influx of calcium (no calcium stores have been demonstrated in filopodia). This calcium signal can cause changes in growth cone signalling and behavior in different ways, largely depending upon the nature of local signal processing in the filopodium. The signal could be directly linked to the central processor without being processed at the peripheral site, that is calcium could directly diffuse to the central growth cone and act as a second messenger, be sequestered or induce emptying of calcium stores. 
Table 1. The growth cone is well equiped for processing information. The list of elements or molecules contained in the growth cone is constantly updated as molecules are identified and/or localised. Only certain elements and molecules have been reported in the filopodia

Growth cone :
organelles
cytoskeletal elements
signalling molecules
and others

central unit
mitochondria
endoplasmic reticulum
calcium stores
ribosomes
microfilaments
microtubules
actin
microtubules binding protein
integrins
calmodulin
PKC
PKA
myosin-light chain kinase
CaM kinase II
Gap 43
myosins
caldesmon
gelsolin
calcineurin

\begin{tabular}{|l} 
filopodia \\
\hline nd \\
nd \\
nd \\
nd \\
microfilaments \\
no \\
actin \\
nd \\
nd \\
calmodulin \\
nd \\
nd \\
nd \\
nd \\
nd \\
nd \\
nd \\
nd \\
nd
\end{tabular}

The signals could have a local effect as a primary messenger that is, remote processing of calcium in filopodia could result in local effects on filopodia with no effects on the central growth cone. Alternatively, input at the periphery may be linked to the central unit via activation of a secondary messenger, that is calcium could activate secondary messenger pathways (e.g. CaM, PKC, etc.) which in turn can modify appropriate targets (e.g. CaM kinase II, MLCK, etc.). Finally the signal could result from the integration of multiple stimuli: multiple receptors may be activated on a single filopodium inducing activation of one or multiple messenger pathways. Summation of responses to these stimuli results in activation of at least one signaling pathway that acts on the growth cone.

Additional variables of calcium's action are the location of its increase and the time course needed to restore resting levels. These critically determine which calcium target is activated and the duration of the activation. The leading question is now to understand how a short-lived elevation of calcium can elicit sustained and long-lasting effects.

\subsection{Spontaneous Calcium Activity on Neurite Outgrowth}

In cultured amphibian spinal neurons spontaneous calcium activity, termed wave activity, has been shown to decrease neurite extension (Gu and Spitzer, 1995). Calcium waves rise and decay slowly over secs to minutes, and occur within restricted regions of the cell; moreover it has been observed that the waves in the soma rise and decay more 


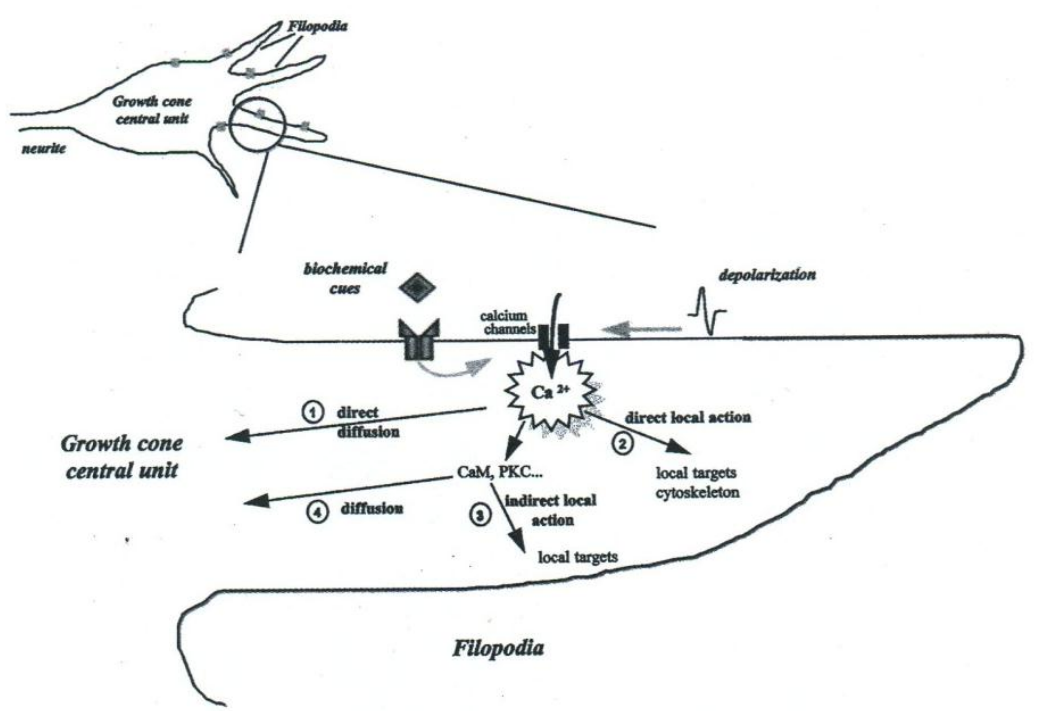

Figure 5. Schematic representation of the functional compartimentalization of the growth cone. Filopodia are the sites of different processing events : linked to $\mathrm{Ca}^{2+}$ influx: 1) diffusion of $\mathrm{Ca}^{2+}$ to the central unit, 2) direct and 3) indirect local actions of $\left.\mathrm{Ca}^{2+}, 4\right)$ diffusion of second messengers activated by $\mathrm{Ca}^{2+}$ (see the text for more detail). Therefore the signal can result from the summation of multiple processing or multiple stimuli.

rapidly than those in the growth cone. In addition, unlike spikes (discussed in section 3.4) which occur for a short period of time during development, waves persist in culture. Waves can be reversibly blocked by $\mathrm{Ni}^{2+}$ indicating that they depend on $\mathrm{Ca}^{2+}$ influx; however, they are not suppressed by blockers at concentrations which are known to suppress voltage dependent $\mathrm{Ca}^{2+}$ and $\mathrm{Na}^{+}$currents, nor are they activated by depolarisation or application of glutamate suggesting that a novel calcium influx pathway is involved. Spitzer and coworkers suggest that calcium waves inhibit neuronal extension via a direct effect on the cytoskeleton (Gu and Spitzer, 1995).

Spontaneous calcium transients have also been observed in growth cones and neurites of chick DRG neurons, but never in the cell body. The calcium transients decreased the rate of neurite extension and like the transients described above they require influx of extracellular calcium through non-voltage gated calcium channels which can be reversibly blocked by $\mathrm{La}^{3+}$ or $\mathrm{Ni}^{+}$(Gomez et al., 1995).

\subsection{Calcium and Axon Guidance}

Axon guidance occurs when axons choose a distinct growth direction in response to a source or orientation of external cues that might be diffusible or fixed. The choice is either positive i.e. axons grow towards a chemoattractant (e.g. NGF, ACh, electrical fields) or negative, i.e. axons avoid a chemorepellent.

4.3.1. Calcium Artificially Increased (by Depolarization) and Axon Growth. The growth cone is rich in voltage-activated calcium channels and the distribution of the dif- 
ferent types of channels has been extensively studied (Anglister et al., 1982; Gottmann and Lux, 1995; Li et al., 1996; Lipscombe et al., 1988; Silver et al., 1990; Vigers and Pfenninger, 1991; Zimprich and Bolsover, 1996). Opening of these channels induced by depolarization or action potentials, leads to an influx of extracellular calcium. N1E-115 neuroblastoma cells submitted to action potentials or $\mathrm{K}^{+}$depolarization show a pronounced increase of the surface area of the growth cone, associated with an increase of neurite elongation and inhibited by blocking $\mathrm{Ca}^{2+}$ channels with $\mathrm{Cd}^{2+}$ (Anglister et al., 1982). The same effect is observed when artificially increasing intracellular calcium with ionophore A23187 (Anglister et al., 1982). By comparing the effect of depolarization on the growth of inactive phasic motor axons and active tonic motor axons of crayfish in culture, Arcaro and Lnenicka (1997) showed that depolarization or application of A23187 produces greater inhibition of phasic axon growth than tonic axon growth. The inhibitory effects of depolarization were reduced by the calcium channels blockers $\mathrm{La}^{3+}$ and $\mathrm{Mg}^{2+}$. This process is calcium dependent and the difference observed is possibly due to differences in $\mathrm{Ca}^{2+}$ regulation and/or sensitivity to intracellular $\mathrm{Ca}^{2+}$.

4.3.2. Axon Guidance and Biochemical Cues. Numerous membrane-bound molecules (cellular or extracellular substrates) supporting or stimulating neurite growth and a number of soluble, diffusible factors (neurotrophins such as NGF) have been found to affect growth cone behavior (review Klostermann and Bonhoeffer, 1996).

4.3.2.1. Membrane Bound Molecules. Axonal growth is mediated by interaction of specific receptors and substrates such as cell adhesion molecules (CAMs), both of the cadherin and immunoglobulin (Ig), and $\beta 1$-class integrin superfamily (Lander, 1989; Doherty et al., 1995; Doherty and Walsh, 1996). It is thought that CAMs mediate interactions with other cells, while integrins mediate interactions with extracellular matrix proteins such as laminin. Although early models of axon growth emphasized the strictly adhesive function of integrins and CAMs, it has been clear for some time that each class of receptor has signaling functions, involving both intracellular messengers and the cytoskeleton. Tyrosine phosphorylation is believed to be an important early step in transduction, both through integrins (Lipfert et al., 1992; Schaller et al., 1994) and through CAMs (Doherty and Walsh, 1994; Ignelzi et al., 1994). While it has become clear that CAMs must function by intracellular signaling, how CAMs function is promoting neurite outgrowth is presently controversial.

A role for $\left[\mathrm{Ca}^{2+}\right]_{\mathrm{i}}$ in mediating the effects of cell adhesion molecules was suggested by results from the laboratory of Doherty and Walsh. Axon outgrowth from PC12 cells and rat cerebellar neurons plated onto a lawn of fibroblasts engineered to express L1 was greater than on parental fibroblasts, but this effect was eliminated if extracellular calcium was reduced, if calcium influx channels were blocked with one of diltiazem, verapamil or nifedipine, or if cytosolic calcium changes were buffered with BAPTA (Williams et al., 1992). Similarly, antibodies to Thy-1, a glycoprotein at the neuronal surface whose ligand is unknown, promoted axon outgrowth from PC12 cells, and this effect was eliminated if extracellular calcium was reduced, if calcium influx channels were blocked with diltiazem, or if cytosolic calcium changes were buffered with BAPTA (Doherty et al., 1993). Doherty and Walsh proposed that CAMs activated calcium channels in the nerve cell membrane, and the resulting calcium influx activated axon advance, as represented in Figure 6 (Doherty and Walsh, 1994). Early experiments in which purified CAMs, or antibodies that bind to CAMs, were applied to neurons revealed a marked $\left[\mathrm{Ca}^{2+}\right]_{\mathrm{i}}$ response (Bixby et al., 1994; Bixby and Jhabvala, 1990; Schuch et al., 1989; von Bohlen und Hal- 


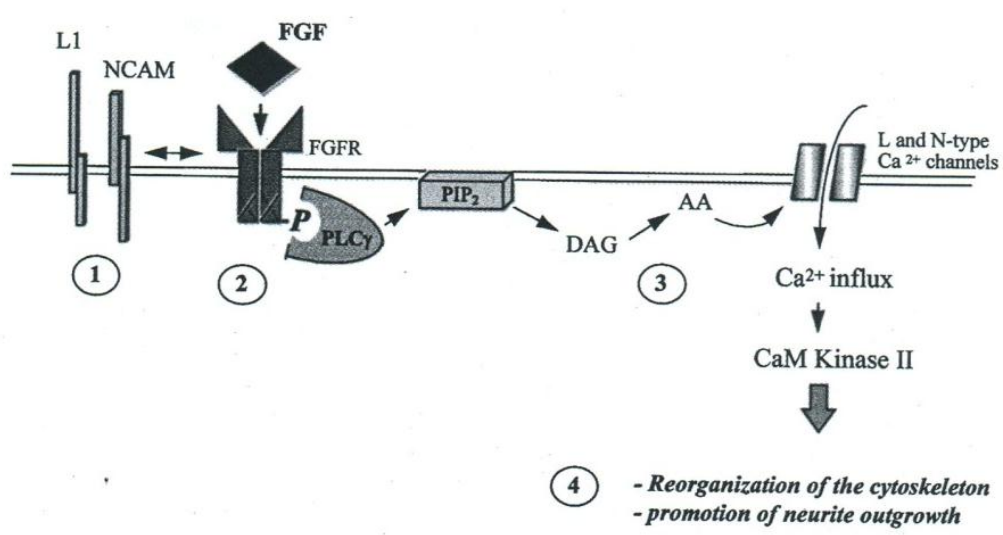

Figure 6. Doherty and Walsh's model of signal transduction by which CAMs, via FGF receptor (FGFR) activation, promote neurite outgrowth. 1) Homophilic and/or heterophilic binding and triggering of CAMs. 2) Activation of the FGFR tyrosine kinase induced by the interaction of the CAMs with the receptor. 3) Signal transduction pathways leading to $\mathrm{Ca}^{2+}$ influx. 4) Effects of this signal on the neurite outgrowth.

bach et al., 1992). More recently, our laboratory has attempted to measure $\left[\mathrm{Ca}^{2+}\right]_{\mathrm{i}}$ when the CAM system is activated at levels that promote axon outgrowth. In no case have we observed a measurable calcium response, either when sensory neuron axons are growing on a lawn of L1-expressing fibroblasts, when PC12 cells are treated with concentrations of anti-L1 antibody that promote neurite outgrowth, or when sensory neuron axons are treated with soluble L1-Fc chimaeras (Archer et al., 1997; Doherty et al., 1993; Harper et al., 1994). Nevertheless, we were able to show that activation of the CAM system does open voltage-operated calcium channels (Archer et al., 1997). We propose that physiological levels of activation of the CAM system produce a very slight opening of high voltage gated calcium channels, mainly L-type. Calcium flowing in through each open channel creates a sub-micron domain of high $\left[\mathrm{Ca}^{++}\right]_{\mathrm{i}}$ at the immediate mouth of the channel, where target proteins can be activated, but the total calcium influx is insufficient to measurably alter bulk growth cone $\left[\mathrm{Ca}^{++}\right]_{\mathrm{i}}$. This mechanism has been previously proposed to explain the activation of downstream processes in non-excitable cells by calcium influx that nevertheless fails to measurably raise $\left[\mathrm{Ca}^{++}\right]_{\mathrm{i}}$ (Alkon and Rasmussen, 1988).

A very similar paradox has been reported by Kater's lab. for the growth promoting action of laminin on Helisoma axons. Contact with a laminin-coated bead promotes axonal outgrowth and turning of the axon towards the bead (Kuhn et al., 1995; Williams et al., 1995). A role for calcium influx is indicated by the finding that removing extracellular calcium, blocking influx, or buffering intracellular calcium, all prevent the response. Nevertheless, no $\left[\mathrm{Ca}^{2+}\right]_{\mathrm{i}}$ response could be measured. In these large invertebrate cells individual filopodia can be dissected off from the growth cone. Contact of such isolated filopodia with laminin coated beads produced a marked $\left[\mathrm{Ca}^{2+}\right]_{\mathrm{i}}$ rise (Williams et al., 1995). Thus it appears that under normal conditions laminin produces a very slight opening of calcium channels in the membrane of the filopodium and creates sub-micron domains of high $\left[\mathrm{Ca}^{2+}\right]_{\mathrm{i}}$ at the immediate mouth of the channels, where target proteins can be activated. Diffusion of calcium ions into the comparatively large volume represented by the main body of the growth cone prevents bulk growth cone $\left[\mathrm{Ca}^{2+}\right]_{\mathrm{i}}$ changing to any measurable extent. In the artificial situ- 
ation of the isolated filopodium the calcium ions entering through the opened channels can no longer escape and the resulting $\left[\mathrm{Ca}^{2+}\right]_{\mathrm{i}}$ increase can be detected.

4.3.2.2. Soluble Cues. The neurotransmitter 5-HT (serotonin) alters growth cones motility and neurite elongation in Helisoma neurons (Haydon et al., 1984). These effects are mediated by increases in $\left[\mathrm{Ca}^{2+}\right]_{\mathrm{i}}$ within the growth cone (Cohan et al., 1987; Murrain et al., 1990). 5-HT causes a receptor-mediated depolarization of the membrane, which results in the opening of voltage sensitive calcium channels. The resulting calcium influx decreases both the elongation rate and the total outgrowth of neurites. Polak et al (1991) have shown that inhibition of calmodulin completely blocked the inhibitory effect of 5-HT on both neurite elongation and total neurite outgrowth. In the absence of 5HT, inhibitors of calmodulin caused a slight decrease in elongation rate but had no significant effect on total outgrowth. Since an additional second messenger, cyclic AMP (cAMP), is known to mediate many physiological effects of neurotransmitters such as 5-HT, Mattson and Kater (1988) have investigated the possible involvement of cAMP in the regulation of neurite outgrowth and the inter-relation between calcium and cAMP. The elevation of the level of cAMP suppressed neurite elongation and growth cone movement. This is prevented by blocking calcium channels or reducing extracellular calcium. However it emerges by studying a larger neuron population that two subpopulations among the neurons whose outgrowth is suppressed by cAMP exist. One subpopulation requires calcium influx for cAMP to act, while the other does not (Mattson et al., 1988). The results suggest that even within a relative small population of neuronal types (such as Helisoma neurons), second messengers within different neurons can act and interact in different ways to regulate outgrowth.

\subsection{Calcium and Turning}

4.4.1. Galvanotropism. Endogenous electrical fields exist in mammalian, chick and amphibian embryos. Their magnitude, spatial and temporal distribution are appropriate for them to act as cues in the developing nervous system, while disturbing endogenous fields specifically disrupts CNS development (McCaig and Erskine, 1996). DRG explant neurites or embryonic spinal neurites from Xenopus larvae in culture show striking response to steady electric fields. A high proportion of cultured neurites reorient, with both turning and branching directed to the cathode. Neurite growth rates are increased and growth is three times faster towards the cathode compared to the anode (Jaffe and Poo, 1979; Stewart et al., 1995). This field-induced cathodal reorientation is partially inhibited by blocking voltage dependent calcium channels with $\omega$-conotoxin and $\omega$-agatoxin GVIA (inhibitors of N-type and P-type channels respectively) or by disrupting calcium release from intracellular stores. In this scheme, it is the imposed asymmetry of $\left[\mathrm{Ca}^{2+}\right]_{\mathrm{i}}$ within the growth cone which results in reoriented growth through its roles in asymmetric microfilament polymerisation and membrane addition.

This increase of calcium may have consequences on other downstream second messengers. The DAG lipase pathway for instance has been referred in the context of promoting outgrowth effect of CAM but has not been tested in field-directed outgrowth. The inhibition of PLC by antibiotics such as neomycin prevent cathodal reorientation (Erskine et al., 1995). The PKC inhibitors sphingosine and H-7 both inhibit cathodal reorientation (Ahmed et al., 1992). Thus the way an electric field is transduced into directed growth is complex. Moreover those pathways could be shared with others guidance cues inducing a cross-talk between activated pathways. 
4.4.2. Turning toward Neurotransmitters. A gradient of neurotransmitter alone can reorient a growth cone. Gradients of NGF have been shown to have in vitro a capacity to reorient DRG neurites (Gundersen and Barrett, 1980). Chick DRG neurites undergo a rapid $(20 \mathrm{~min})$ reorientation of their direction of growth in response to a NGF concentration gradient. The growth cones turned and grew towards these NGF sources.

Recent experiments using polystyrene beads covered with NGF have shown that growth cones rapidly turned and migrated under NGF-coated beads in a process that involved the initial formation of the contact followed by direct flow of cytoplasm toward the point of contact. The prevention of turning by the inhibition of the high affinity NGF receptor trkA, suggests a role for the local activation of this receptor in chick DRG neurons (Gallo et al., 1997). Moreover trkA has been shown to mediate an increase of intracellular calcium. While insensitive to chelation of extracellular $\mathrm{Ca}^{2+}$, this increase is abolished following depletion of $\mathrm{Ca}^{2+}$ stores or blockade of intracellular $\mathrm{Ca}^{2+}$ release, providing strong evidence that intracellular calcium is the main source of NGF response (De Bernardi et al., 1996).

A focal source of $\mathrm{ACh}$ or glutamate released in a pulsatile manner from a micropipette tip can be used to establish a gradient of neurotransmitter. Xenopus growth cones sense this and reorient to grow up the gradient within a matter of minutes; a response which involves an elevated intracellular calcium concentration (Zheng et al., 1996; Zheng et al., 1994). More filopodia were observed on the side of the growth cone facing towards the source of the gradient. A uniform increase of $\mathrm{Ca}^{2+}$ at the growth cone resulting from $\mathrm{Ca}^{2+}$ influx may modulate motility of the growth cone but it is unlikely to provide the growth cone with directional information. An asymmetric or very localized influx of $\mathrm{Ca}^{2+}$ could produce a gradient of $\mathrm{Ca}^{2+}$ into the growth cone leading to growth cone turning. Zheng (1994) showed one rare growth cone which showed a higher increase in $\left[\mathrm{Ca}^{2+}\right]_{\mathrm{i}}$ at the side proximal to the ACh source and eventually turned towards it. The failure to detect such local and small increases of $\mathrm{Ca}^{2+}$ in a higher fraction of the growth cones may be due to temporal and spatial limitations of the actual imaging methods.

\subsection{Calcium and Retraction/Collapse}

4.5.1. Filopodia and Veil Growth/Retraction. Filopodia contain mainly actin filaments (Letourneau, 1983) whose polymerization and depolymerization can be regulated by $\left[\mathrm{Ca}^{2+}\right]_{\mathrm{i}}$ (discussed below). Local elevation of $\left[\mathrm{Ca}^{2+}\right]_{\mathrm{i}}$ by focal application of an electrical field or transmitters can induce rapid filopodial protusion, presumably by modifying actin dynamics (Bedlack et al., 1992; Davenport and Kater, 1992). Activity-driven Ca ${ }^{2+}$ "hotspots" have been observed in growth cones of neuroblastoma cells, rat sensory neurones and Aplysia motoneurons (Amato et al., 1996; Connor et al., 1990; Silver et al., 1990). This locally high $\left[\mathrm{Ca}^{2+}\right]_{\mathrm{i}}$ can trigger outgrowth of veils, perhaps by triggering exocytosis (Lockerbie et al., 1991; Silver et al., 1990) and outgrowth of filopodia (Davenport and Kater, 1992).

\subsubsection{Calcium and Collapse.}

4.5.2.1. Electrical Activities. The refinement of the developing nervous system is achieved by mechanisms that include cell death, selective growth and loss of neurites and the stabilization and elimination of synapses. The role of electrical activity is particularly important in selective neurite retraction during development. In developing neurons the frequency and duration of ongoing impulses determine the final arborizations and the pattern of connections. When impulse activity is silenced, axons fail to retract branches that 
had grown to inappropriate destinations in the mammalian visual system, cerebellum and neuromuscular junctions.

A train of action potentials in an actively growing neuron and the resulting increase in intracellular calcium results in the abrupt retraction of filopodia, shrinkage of lamellipodia and arrest or collapse of the growth cone. The source of this calcium increase is mainly through HVA calcium channels. The growth of both mouse DRG and Helisoma neurons is arrested when the cells are electrically stimulated (Cohan and Kater, 1986; Fields et al., 1990). A.pplication of $\mathrm{K}^{+}$to the external medium causes a dose-dependent suppression of neurite elongation. Lower concentrations of $\mathrm{K}^{+}$are associated with a slowing in the rate of neurite elongation, whereas higher concentration produces neurite retraction. Depolarization-induced changes in neurite elongation are blocked by application of calcium antagonists (Cohan, 1992). Recent studies are focusing on how electrical stimulation influences the magnitude, time course and regional levels of free intracellular calcium. In Helisoma neurons, calcium levels increase monotonically with increasing stimulation frequency. The increase in calcium concentration is much smaller in the cell bodies than in the growth cones and neurites (Torreano and Cohan, 1997).

Another aspect of electrical stimulation is that DRG neuron cultures exposed to electrical stimulation for several hours contained actively growing neurites with normal growth cones which were insensitive to the stimulation (Fields et al., 1993; Fields et al., 1990). Continuous stimulation induced a significant rise of the calcium concentration level, which in many cases exceeded the concentration of calcium that induced collapse initially. However the growth cone does not collapse. This apparent insensitivity in neurites exposed to chronic stimulation suggests some accomodating processes related to calcium influx, efflux, or buffering. The rapid increase in calcium in naive growth cones may activate biochemical processes inhibitory to growth cone structure and motility, whereas a slower increase in calcium may permit time for regulatory or compensatory mechanisms to allow growth and motility. This idea is strengthened by recent results from Diefenbach \& Kater (1997), showing that the specific inhibition of CaM Kinase II in trained DRG, restore the full collapse response when new stimulation is applied. They hypothesise that the conditioned response is dependent on $\mathrm{Ca}^{2+} / \mathrm{CaMK}$ II and this kinase would have a protective effect.

4.5.2.2. Repulsive Cues. Besides extension-promoting cues, a growth cone is also exposed to negative guidance cues. Much less information is available on this class of recently discovered guidance factors. Some cues can promote outgrowth and guidance in one type of neuronal cells while inducing collapse in another neuronal cell type e.g. netrins promote outgrowth of commissural axons in the spinal cord (Serafini et al., 1994) but have a repulsive activity for trochlear motor axons (Colamarino and Tessier Lavigne, 1995). Moreover it is known that different cues can induce the same collapse in a given type of cell and that two different signaling systems mediating collapse can coexist within the neuronal growth cone (Loschinger et al., 1997).

One prominent example is NI-35, an inhibitor found in axon extract from CNS myelin (Bandtlow et al., 1990; Caroni and Schwab, 1988; Schwab, 1990). Both dantrolene (a ryanodine receptor inhibitor) and pertussis toxin have been shown to block the collapseinducing effect of NI-35 on growth cones of DRG cells (Bandtlow et al., 1993; Igarashi et al., 1993). NI-35-induced collapse is clearly $\mathrm{Ca}^{2+}$ dependent in DRG growth cones (Loschinger et al., 1997) and in locus coeruleus growth cones (Moorman and Hume, 1994). In DRG growth cones $\left[\mathrm{Ca}^{2+}\right]_{\mathrm{i}}$ increased sevenfold preceding collapse. DRG growth cones recover in several hours whereas chick retinal axons recover in less than $10 \mathrm{~min}$, that is, recovery is cell type-dependent (Bandtlow et al., 1993). Kim and coworkers (1993) have 
proposed that activation of a G-protein coupled receptor for NI-35 leads to activation of a membrane-bound ADP ribosyl cyclase and production of cyclic-ADP ribose. Cyclic-ADP ribose could activate ryanodine receptors inducing a release of $\mathrm{Ca}^{2+}$ from intracellular stores (Galione, 1992). The recent work of Loschinger et al (1997), who showed that NI35 -induced collapse is clearly $\mathrm{Ca}^{2+}$ dependent, is consistent with this model. $\left[\mathrm{Ca}^{2+}\right]_{\mathrm{i}}$ increased sevenfold preceding collapse, and both dantrolene and antibodies against NI-35 significantly reduced both the $\mathrm{Ca}^{2+}$ increase and the collapse frequency.

In contrast to that example, $\mathrm{Ca}^{2+}$ does not seem to play a crucial role either in the action of collapsin (Ivins et al., 1991) nor in the repulsive activity derived from the posterior optic tectum (p-membranes) which induced collapse of chick DRG growth cones (Loschinger et, al., 1997).

\section{DOWNSTREAM PATHWAYS}

\subsection{Known Target Processes}

5.1.1. Actin Assembly-Disassembly. Active outgrowth involves insertion of membrane components (Futerman and Banker, 1996; Vogt et al., 1996), assembly and disassembly of microtubules (Lankford et al., 1990), organization and reorganization of actin filaments, and movements of organelles, as summarised in Figure 7. The cycle of filopodial and lamellipodial protusion, adhesion and generation of tension to move a growth cone results from the concerted actions of actin-binding proteins to regulate actin filament polymerisation and assembly into networks and bundles. The direction of neurite elongation is controlled by forward movement of microtubules into growth cones. Actin filaments both promote and impede the advance of microtubules in several ways.

Calcium regulates the organization and functions of actin filaments, either by binding to actin-binding proteins, or through an intermediate such as calmodulin (Janmey, 1994). Different components of the actin cytoskeleton may be differentially sensitive to calcium changes. For example, Lankford and Letourneau $(1989 ; 1991)$ showed that moderate increases in intracellular calcium cause a loss of lamellipodial actin, while filipodial actin is spared. Sobue and Kanda (1989) found calcium-sensitive and -insensitive form of $\alpha$-actinin. $\mathrm{Ca}^{2+}$-sensitive $\alpha$-actinin and actin filaments are concentrated in filopodia whereas the $\mathrm{Ca}^{2+}$-insensitive protein is distributed from the body of the growth cone to the distal portion of neurites. They speculate that $\mathrm{Ca}^{2+}$-sensitive $\alpha$-actinin and actin filaments are involved in $\mathrm{Ca}^{2+}$-dependent filopodial movement and $\mathrm{Ca}^{2+}$-insensitive $\alpha$-actinin and calspectin are associated with adhesion of growth cones. When $\left[\mathrm{Ca}^{2+}\right]_{i}$ is elevated, actin filament cross linking with $\alpha$-actinin is disrupted, gelsolin is activated to sever and cap actin filaments and gCAP-39 is activated to sequester actin monomers. In sum, elevated $\left[\mathrm{Ca}^{2+}\right]_{\mathrm{i}}$ leads to breakdown of actin bundles as well as loss of microtubules, while depression of $\left[\mathrm{Ca}^{2+}\right]_{\mathrm{i}}$ may decrease dynamic remodeling of actin filament system (Kater and Mills, 1991; Lankford and Letourneau, 1989; Lankford and Letourneau, 1991).

5.1.2. Calcium and Exocytosis in Neuronal Growth. One of the requisites of neuronal growth is the insertion of new membrane materials at the growing points (Futerman and Banker, 1996). The cellular process involved in addition of cell surface components is presumed to be the fusion of vesicles at the sites of expansion, perhaps via the SNARE system proposed for synaptic vesicle exocytosis (reviewed recently by Calakos and Scheller, 1996; Matthews, 1996; Zucker, 1996). Evidence that this mechanism may be involved 


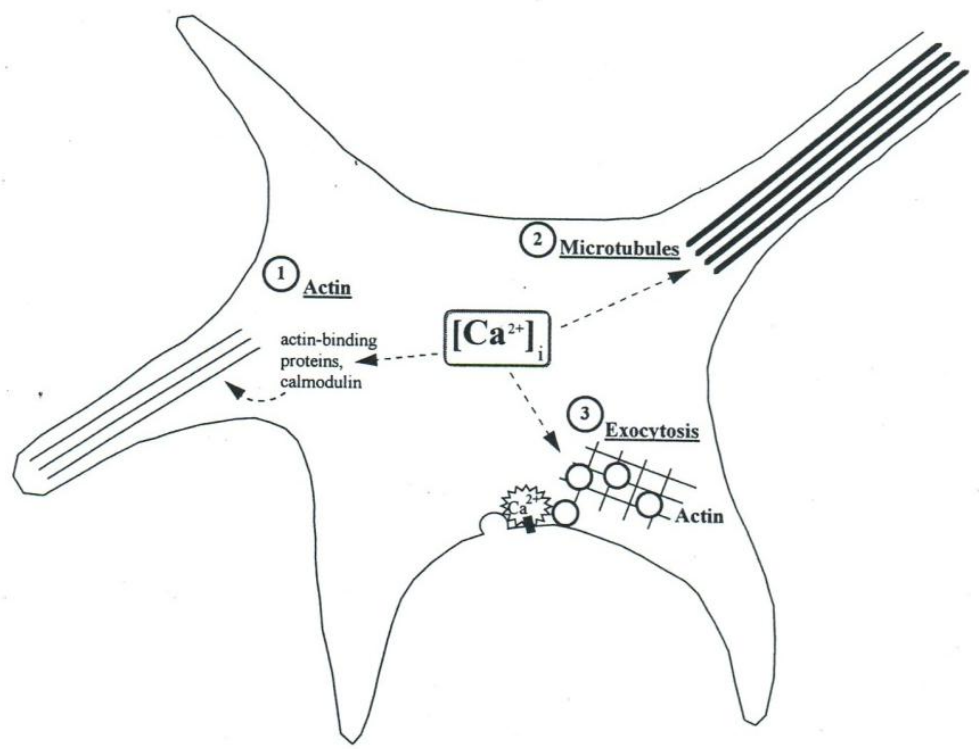

Figure 7. A summary of calcium targeted processes in the growth cone that may influence its growth and motility. 1) Calcium regulates the organisation of actin filaments in the body and processes of the growth cone. Calcium can bind either to actin-binding proteins directly or act through intermediates such as calmodulin. 2) Calcium can also influence microtubule assembly and disassembly in the body of the growth cone. 3) Calcium is known to play a major role in regulated exocytosis and in the growth cone may regulate addition of new membrane at the growing points.

in neuronal growth comes firstly from application of antisense RNAs against SNAP-25 (an important component of the exocytotic machinary at the presynaptic nerve terminal) which was shown to retard growth (Osen-Sand et al., 1993). Furthermore, proteolytic cleavage of syntaxin (another component of the presynaptic exocytotic machinary) by neurotoxin $\mathrm{C} 1$ was shown to cause growth cone collapse, further implicating this exocytotic mechanism in elongation at the growth cone tip (Igarashi et al., 1996). Calcium is thought to have an important role in regulated exocytosis and there are several proposals as to how and where calcium acts during vesicle fusion (reviewed by Bennett, 1997; Burgoyne and Morgan, 1995, see also Chapter 10). Thus it seems likely that calcium is also involved in vesicle fusion at the growing points of neurites. Lockerbie and coworkers (1991), using isolated nerve growth particles reported that influx of extracellular calcium causes addition of new membrane to the plasmalemma and these authors suggest that this is dissociated from transmitter release. Thus calcium may have a direct effect on neuronal growth by causing exocytosis and thus addition of membrane at sites of growth (as shown in figure 7). Calcium and exocytosis are described in more detail in chapter 10.

\subsection{Known Target Proteins that May Mediate These Processes}

5.2.1. Calmodulin (CaM). Calmodulin has 4 calcium-binding EF hand domains and is a major intracellular receptor mediating the actions of calcium via interaction with nu- 


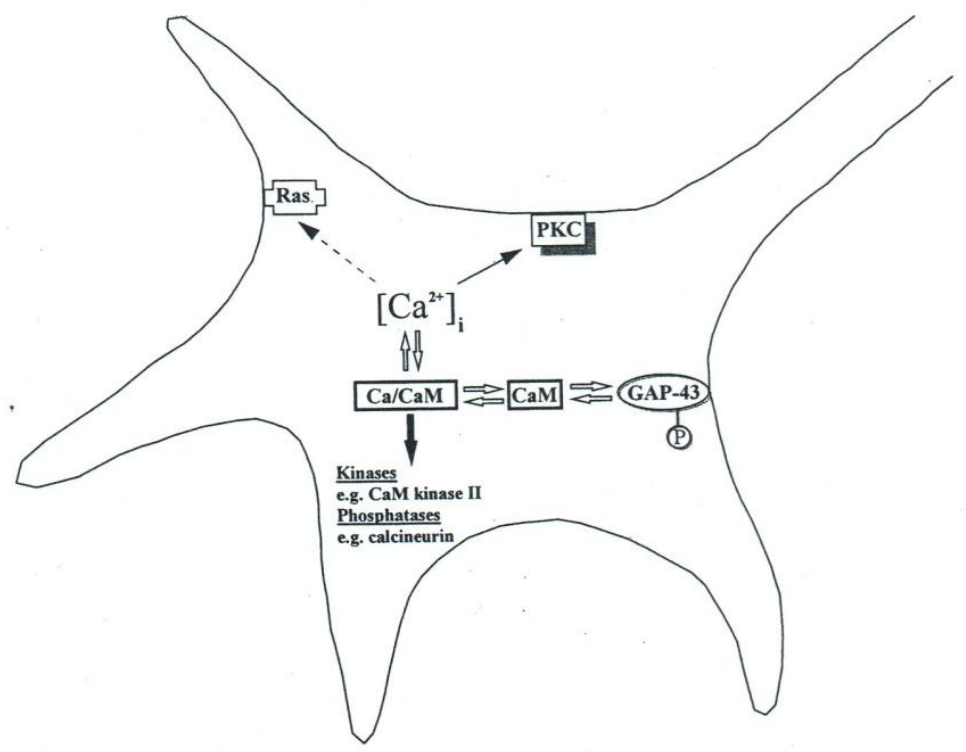

Figure 8. A summary of some of the calcium activated target proteins and subsequent downstream signalling cascades that are located in the neuronal growth cone. Calmodulin (CaM), Protein kinase C (PKC).

merous target proteins, see Figure 8 (Niki et al., 1996). CaM is detected in both the cytoplasm and in the nucleus where the $\mathrm{Ca}^{2+} / \mathrm{CaM}$ complex regulates a number of different activities (Bachs et al., 1994; Carafoli et al., 1997, see also Chapter 2). Because CaM is such an ubiquitous messenger with so many different targets this creates difficulties in pinning down its specific roles in neuronal growth and development. One study using Drosophila has selectively expressed novel genes encoding $\mathrm{CaM}$ inhibitors or calcium binding proteins in growth cones of a subset of pioneer neurons undergoing axogenesis. This selective disruption of the signalling pathway in the growth cone caused errors in neuron extension and guidance, evidence that $\mathrm{Ca}^{2+} / \mathrm{CaM}$ has a role in neuronal pathfinding in vivo (Vanberkum, 1996; VanBerkum and Goodman, 1995). Another study investigating the effects of overexpressing and underexpressing calmodulin in PC12 cells showed that reduced levels of calmodulin caused neurite outgrowth (Davidkova et al., 1996), thus calmodulin is implicated in neuronal differentiation.

5.2.2. CaM Kinase. Many of the intracellular processes regulated by the $\mathrm{Ca}^{2+} / \mathrm{CaM}$ complex are controlled by phosphorylation and dephosphorylation, hence a major target for $\mathrm{Ca}^{2+} / \mathrm{CaM}$ is a family of $\mathrm{Ca} / \mathrm{CaM}$ kinases, termed CaM kinases (Nairn and Picciotti, 1994; Soderling, 1996).

CaM kinase II is probably the most well defined CaM kinase and it is particularly abundant in neural tissue where it acts on a variety of substrates (Braun and Schulman, 1995; Hanson and Schulman, 1992, see also Chapter 2). The enzyme has the capability for intrinsic autophosphorylation allowing it to remain active following a decrease in the calcium signal and thus has been proposed to act as a frequency detector integrating calcium 
oscillations (Braun and Schulman, 1995). CaM kinase II is expressed in a variety of different isoforms at different stages of neuronal development indicative of a functional significance (e.g. Brocke et al., 1995; Jia et al., 1992; Nomura et al., 1997; Sakagami and Kondo, 1993). Overexpression of the enzyme appeared to promote neurite outgrowth and growth cone motility in neuroblastoma cell lines (Goshima et al., 1993; Nomura et al., 1997). However activation of CaM kinase II in cultured Drosophila neurons inhibited neurite outgrowth and branching (Broughton et al., 1996). Outgrowth of cerebellar neurons in response to FGF or cell adhesion molecules is abolished by the CaM kinase II inhibitor KN-62 (Williams et al., 1995). This suggests that CaM kinase activity is required downstream of calcium influx in the CaM and FGF signaling pathway leading to axonal growth. Thus there is evidence that $\mathrm{CaM}$ kinase II may have a role in neuronal outgrowth although its function is far from clear.

CaM kinase I was originally detected in brain based on its ability to phosphorylate the synaptic vesicle protein synapsin I . It is now found to be a multifunctional enzyme expressed in adult animals at high levels in certain areas of the brain as well as in many other tissues (reviewed by Picciotto et al., 1996). CaM kinase I shows developmentally regulated gene expression patterns in various regions of rat brain suggesting that it may have a signalling role during brain development (Sawamura et al., 1996).

The other member of the CAM kinase family that has been relatively well studied is CaM kinase IV. Like CaM kinase I, CaM kinase IV shows differential expression in the rat brain during development suggesting a signalling role in developing neurons and is reported to have significant nuclear localisation where it can phosphorylate various transcription factors (Sakagami et al., 1994; Sakagami et al., 1992).

5.2.3. Calcineurin. Calcineurin is a $\mathrm{Ca}^{2+} / \mathrm{CaM}$ dependent protein phosphatase which has an important role in the control of intracellular $\mathrm{Ca}^{2+}$ signalling. In brain calcineurin has been found in high concentrations in neurons, in particular those of neurostriatum and cerebellum (Klee et al., 1990). Calcineurin is activated by calmodulin, following calcium entry into the cell. As the presence of calmodulin binding proteins such as calcineurin or CaM kinase II, strongly enhances calcium binding to calmodulin, it is still very difficult to define the extent and the timing of calcineurin activation (Guerini, 1997). During the initial outgrowth of cerebellar neurons in culture, calcineurin is enriched in growth cones, where its localization depends upon the integrity of both microtubules and actin filaments (Ferreira et al., 1993). Thus calcineurin is well positioned to mediate interactions between cytoskeletal systems during neurite elongation. Chang et al (1995) have indirectly shown the role of calcineurin in neurite outgrowth and filopodial motility in cultured chick DRG neurons. First, inhibition of calcineurin with specific inhibitors (cyclosporin A and FK506) inhibit neurite extension. Second, focal inactivation of calcineurin in regions of growth cones causes localized filopodial and lamellipodial retraction and influences direction of subsequent outgrowth. At the same time, studies on the cellular mechanisms that couple membrane depolarization and gene expression have shown that calcineurin mediates the response by modifying the phosphorylation state of CREB (Bito et al., 1996).

5.2.4. Neuronal Calcium Sensor NCS-1. NCS-1 is a calcium binding protein with 2 calcium-binding domains that shows only $22 \%$ homology with calmodulin. NCS- 1 is able to activate directly two $\mathrm{Ca}^{2+} / \mathrm{CaM}$-dependent enzymes ( $3^{\prime}: 5^{\prime}$-cyclic nucleotide phosphodiesterase and protein phosphatase calcineurin) (Schaad et al., 1996). NCS-1 is co-expressed with calcineurin in several neuron populations which make this novel protein capable of mediating multiple $\mathrm{Ca}^{2+}$-signalling pathways in the nervous system. 
5.2.5. Ras. p2 $1^{\text {ras }}$ (Ras) is a small guanine nucleotide-binding protein that functions in signal transduction cascades that mediate cellular growth and differentiation. Ras is highly expressed in the developing and the adult nervous system. Ras is localised to the inner surface of the membrane and functions as a molecular switch that transmits receptor signals to downstream mitogen-activated protein kinase (MAPK) cascades (Seger and Krebs, 1995). Phosophorylated MAPK translocates to the nucleus and induces gene expression (Segal and Greenberg, 1996). It has been shown that influx of calcium through voltage-gated calcium channels can activate Ras (Rosen et al., 1994). It emerges now that four different $\mathrm{Ca}^{2+}$-dependent pathways are able to activate Ras (see for Finkbeiner and Greenberg, 1996). These pathways may have critical roles in $\mathrm{Ca}^{2+}$-dependent signals and long-term changes in neuronal differentiation, survival and synaptic strength. But because of possible cross-talk between the pathways, the proper independence of these pathways is far from being clear.

5.2.6. Protein Kinase $C(P K C)$. Protein kinase $\mathrm{C}$ is a family of $\mathrm{Ser} / \mathrm{Thr}$ kinases which can be broadly divided into three categories, those that are calcium sensitive and require DAG for activation, those that are calcium insensitive but require DAG and those that are described as atypical (Liu, 1996). There are differences in both the tissue and subcellular localisation of the PKC isotypes suggesting a functional divergence. In the nervous system there is differential expression of isoforms during development, evidence for a role for PKC in neuronal growth and maturation (Tanaka and Nishizuka, 1994).

Calcium dependent PKC isoenzymes have been shown to be localised within neurites; however their role is still unclear (Campenot et al., 1994). Doherty and coworkers have showed that inhibiting PKC reduces neurite outgrowth in cerebellar granule cells (Doherty et al., 1994). Similarly, the protein kinase C inhibitors H7 and sphingosine inhibit outgrowth from ciliary ganglion neurons whilst the phorbol ester TPA (an activator of protein kinase C) potentiates neurite outgrowth (Bixby, 1989). In cultured embryonic cortical neurons inhibition of PKC led to a rapid change in the growth cone analogous to collapse morphology (Theodore et al., 1995) and there is also evidence that PKC promotes outgrowth of spinal neurons (Qian et al., 1994). Conversely, in neuroblastoma cells, activation of PKC inhibited neurite outgrowth whilst inhibition of PKC increased neurite outgrowth (Nomura et al., 1997; Tint et al., 1992).

5.2.7. Gap-43. GAP-43 is a protein whose expression in vivo is almost exclusively confined to the nervous system, where it is located mainly on the cytoplasmic face of presynaptic terminals. It is upregulated during initial development of the CNS and also in regeneration of the PNS (see reviews Benowitz and Routtenberg, 1997; Caroni, 1997). There is much evidence that GAP-43 is an intrinsic determinant of axonal sprouting and elongation and it appears that the phosphorylation state of GAP-43, especially at ser41, is important for its role in neuronal outgrowth (Aigner et al., 1995).

The role of calcium in regulating GAP-43 seems to be indirect. The GAP-43 protein contains an IQ domain and binds CaM independently of calcium. GAP-43 is phosphorylated on ser41 by PKC and on two other sites by other kinases and is dephosphorylated by both $\mathrm{Ca}$-independent phosphatases and calcineurin.

There are several hypotheses as to the role of GAP-43. One suggestion is that GAP-43 can act as a CaM "sponge", so that in low $\left[\mathrm{Ca}^{2+}\right]_{\mathrm{i}}$ conditions calmodulin is sequestered at specific submembrane regions in the axonal terminal. Consequently, upon activation, $\left[\mathrm{Ca}^{2+}\right]_{\mathrm{i}}$ mobilisation at these regions would allow rapid activation of downstream signaling cascades (Pate Skene, 1990). Alternatively, Benowitz and Routtenberg (1997) propose that because 
GAP-43 is effective in its phosphorylated (CaM independent) state, its role is more than just a $\mathrm{CaM}$ buffer. Upon activation of second messengers cascades (e.g. $\left.\mathrm{Ca}^{2+}\right) \mathrm{CaM}$ dissociates and the subsequent phosphorylation of GAP-43 inhibits reassociation of CaM allowing GAP-43 to remain active. The activation of $\mathrm{Ca}^{2+} / \mathrm{CaM}$ sensitive messengers e.g. calcineurin may then feedback on GAP-43 to dephosphorylate the protein (Benowitz and Routtenberg, 1997).

The fact that GAP-43 is neuron specific and located on the cytoplasmic face of the presynaptic terminal has also led to the suggestion that GAP-43 has a role in synaptic vesicle docking and fusion. There is evidence that GAP-43 is involved in $\mathrm{Ca}^{2+}$-dependent neurotransmitter release (see review Calakos and Scheller, 1996); however the role of GAP-43 in exocytosis remain to be fully determined.

\subsection{Induction of Gene Expression}

'Activity-dependent changes in neuronal structure and synaptic terminals depend critically on protein synthesis. Recent studies permit identification of some of the mechanisms involved in activity-dependent surface-to-nucleus signaling in neurons. The nucleus acts as an information-processing sensor, receiving inputs derived from surface stimuli that are transferred centrally via diverse cytoplasmic signals. Both devices (surface or nucleus) are clearly sensitive to the intensity, duration and temporal pattern of incoming signals within the axon or dendrites. In neurons, voltage-dependent $\mathrm{Ca}^{2+}$ channels, NMDA and growth hormone receptors are able to respond quickly to events by generating $\mathrm{Ca}^{2+}$ signals and, depending on its route of entry, calcium may activate distinct signal transduction pathways leading to different patterns of gene expression. Activation of NMDA receptors would lead to a sustained, high-amplitude $\mathrm{Ca}^{2+}$ influx, while opening of voltage gated calcium channels would lead to a transient, low-amplitude $\mathrm{Ca}^{2+}$ influx. This signaling cascade provides a reason why $\mathrm{Ca}^{2+}$ may be an important mediator of membrane-tonucleus signaling (Gallin and Greenberg, 1995; Ginty, 1997, and Chapter 3).

Importance of $\mathrm{Ca}^{2+}$ entry has been demonstrated by disrupting signaling to the nucleus with blockers of NMDA receptors and inhibitors of voltage-gated $\mathrm{Ca}^{2+}$ channels (Deisseroth et al., 1996). Calcium can stimulate gene expression via distinct pathways (i.e. serum response factor (SRE) and CRE (cyclic AMP response element)-linked pathways) that can operate independently of the Ras/MAP kinases signaling cascade in a cell typedependent manner (Johnson et al., 1997).

Most of the recent studies relate to synaptic plasticity. However it is now necessary to determine if the signaling cascades (discussed above) exist in the developing neuron encountering or reaching a zone of high electrical activity (such as the polarized membrane of a muscle cell) or a gradient of biochemical cues (e.g. growth factors, CAMs).

\subsection{Exocytotic Machinery}

There are several different molecules that have been put forward as targets for calcium during regulated exocytosis (see chapter 10 for details) (reviewed recently in Bennett, 1997; Calakos and Scheller, 1996; Zucker, 1996). Synaptotagmin is an integral membrane protein found in synaptic vesicles and a leading candidate as the calcium sensor for neurotransmission; however its precise role is still debated. It has a high affinity for calcium and thus may act in a slower phase of release, perhaps having a role in forming a pool of readily releasable docked vesicles. Rabphilin and doc2 are also localised to synaptic vesicles and contain $\mathrm{Ca}^{2+}$-dependent phospholipid binding domains. Whether any of these proteins are involved in exocytosis during neuronal growth remains to be determined. 
Syntaxin may be involved in neurite outgrowth as discussed in the section on calcium and exocytosis in neuronal outgrowth. It is a plasma membrane protein localised in axons and nerve terminals and is associated with synaptotagamin and $\mathrm{N}$-type calcium (Leveque et al., 1994; Sheng et al., 1996; Sheng et al., 1994). SNAP-25 is another synaptic protein which is differentially expressed during neuronal development (Oyler et al., 1991 ) and is also involved in neuronal outgrowth as discussed earlier.

\section{CONCLUSION}

This chapter shows that calcium can control and modulate many cellular functions during neuronal development. How calcium can act in a selective fashion is only recently becoming more precisely defined. It is clear that the temporal and spatial encoding of the calcium signal.(e.g., local or global $\mathrm{Ca}^{2+}$ rises, spikes and waves) causes various different responses within the neuron (e.g. local or global, short or longer lasting responses). One of the next challenges is to understand how the developing neuron integrates the different aspects of calcium signalling during its journey to become a mature and functional neuronal cell. Moreover, as the majority of information on calcium signalling during nerve growth is derived from studies in vitro, it will be important in the future to define which aspects are relevant in vivo.

\section{REFERENCES}

Ahmed T, Erskine L, Shewan DA, Stewart R \& McCaig CD (1992) Neurotransmitters, second messengers and protein kinase $\mathrm{C}$ may underlie orientation of cultured frog nerves in an applied electric field. J Physiol (Lond) 446, 42P.

Aigner L, Arber S, Kapfhammer J P, Laux T, Schneider C, Bottrei F, Brenner H-R \& Caroni P (1995) Overexpression of the Neural Growth-Associated Protein GAP-43 Induces Nerve Sprouting in the Adult Nervous System of Transgenic Mice. Cell 83, 269-278.

al Mohanna FA, Cave J \& Bolsover SR (1992) A narrow window of intracellular calcium concentration is optimal for neurite outgrowth in rat sensory neurones. Brain Res Dev Brain Res 70, 287-290.

Alkon DL \& Rasmussen H (1988) A spatial-temporal model of cell activation. Science 239, 998-1005.

Amato A, Al-Mohanna FA \& Bolsover SR (1996) Spatial organization of calcium dynamics in growth cones of sensory neurones. Dev Brain Res 92, 101-110.

Anglister L, Farber IC, Shahar A \& Grinvald A (1982) Localization of voltage-sensitive calcium channels along developing neurites: their possible role in regulating neurite elongation. Dev Biol 94, 351-365.

Archer F, Doherty P \& Bolsover SR (1997) Cell adhesion molecules induce calcium influx in neurons developing in culture. Soc Neurosci Abstracts 23, 767-762.

Bachs O, Agell N \& Carafoli E (1994) Calmodulin and Calmodulin-binding Proteins in the Nucleus. Cell Calcium 16, 289-296.

Bandtlow C, Zachleder T \& Schwab ME (1990) Oligodendrocytes arrest neurite growth by contact inhibition. $J$ Neurosci 10, 3837-3848.

Bandtlow CE, Schmidt MF, Hassinger TD, Schwab ME \& Kater SB (1993) Role of intracellular calcium in NI-35evoked collapse of neuronal growth cones. Science 259, 80-83.

Bang AG \& Goulding MD (1996) Regulation of vertebrate neural cell fate by transcription factors. Curr Opin Neurobiol 6, 25-32.

Bedlack RS Jr, Wei M \& Loew LM (1992) Localized membrane depolarizations and localized calcium influx during electric field-guided neurite growth. Neuron 9, 393-403.

Bennett MK (1997) $\mathrm{Ca}^{2+}$ and the regulation of neurotransmitter secretion. Curr Opin Neurobiol 7, 316-322.

Benowitz LI \& Routtenberg A (1997) GAP-43: an intrinsic determinant of neuronal development and plasticity. Trends Neurosci 20, 84-91.

Bito H, Deisseroth K \& Tsien RW (1996) CREB phosphorylation and dephosphorylation: a $\mathrm{Ca}^{2+}$ - and stimulus duration-dependent switch for hippocampal gene expression. Cell 87, 1203-1214. 
Bixby JL (1989) Protein kinase C is involved in laminin stimulation of neurite outgrowth. Neuron 3, $287-297$.

Bixby JL, Grunwald GB \& Bookman RJ (1994) $\mathrm{Ca}^{2+}$ influx and neurite growth in response to purified N-cadherin and laminin. $J$ Cell Biol 127, 1461-1475.

Bixby JL \& Jhabvala P (1990) Extracellular matrix molecules and cell adhesion molecules induce neurites through different mechanisms. J Cell Biol 111, 2725-2732.

Braun AP \& Schulman H (1995) The Multifunctional Calcium/Calmodulin-dependent Protein Kinase: From Form to Function. Ann Rev Physiol 57, 417-445.

Brocke Srinivasan M \& Schulman H (1995) Developmental and Regional Expression of Multifunctional Ca ${ }^{2+} / \mathrm{cal}^{2}$ modulin-Dependent Protein Kinase Isoforms in Rat Brain. J Neurosci 15, 6797-6808.

Broughton SJ, Kane NS, Yoder M, Greenspan RJ \& Robichon A (1996) Transport of CaM kinase along processes elicited by neuronal contact evokes an inhibtion of arborization and outgrowth in D. Melanogaster cultured neurons. J Cell Biol 62, 484-494.

Burgoyne RD \& Morgan A (1995) $\mathrm{Ca}^{2+}$ and secretory-vesicle dynamics. Trends Neurosci 18, 191-196.

Calakos N \& Scheller RH (1996) Synaptic vesicle biogenesis, docking, and fusion: A molecular description. Physiol Rev 76, 1-29.

Campenot RB, Draker DD \& Senger DL (1994) Evidence that protein kinase C activities involved in regulating neurite growth are localized to distal neurites. $J$ Neurochem $63,868-78$.

Carafoli E (1987) Intracellular calcium homeostasis. Annu Rev Biochem 56, 395-433.

Carafoli E, Nicotera P \& Santella L (1997) Calcium signalling in the cell nucleus. Cell Calcium 5, 313-320.

Caroni P (1997) Intrinsic neuronal determinants that promote axonal sprouting and elongation. Bioessays 19, 767-775.

Caroni P \& Schwab ME (1988) Two membrane protein fractions from rat central myelin with inhibitory properties for neurite growth and fibroblast spreading. J Cell Biol 106, 1281-1288.

Clapham DE (1995) Calcium signaling. Cell 80, $259-68$.

Cohan CS (1992) Depolarization-induced changes in neurite elongation and intracellular $\mathrm{Ca}^{2+}$ in isolated Helisoma neurons. J Neurobiol 23, 983-96.

Cohan CS, Connor JA \& Kater SB (1987) Electrically and chemically mediated increases in intracellular calcium in neuronal growth cones. $J$ Neurosci 7, 3588-99.

Cohan CS \& Kater SB (1986) Suppression of neurite elongation and growth cone motility by electrical activity. Science 232, 1638-1640.

Colamarino SA \& Tessier Lavigne M (1995) The axonal chemoattractant netrin-1 is also a chemorepellent for trochlear motor axons. Cell 81, 621-629.

Connor JA, Kater SB, Cohan C \& Fink L (1990) $\mathrm{Ca}^{2+}$ dynamics in neuronal growth cones: regulation and changing patterns of $\mathrm{Ca}^{2+}$ entry. Cell Calcium 11, 233-239.

Davenport RW, Dou P, Rehder V \& Kater SB (1993) A sensory role for neuronal growth cone filopodia. Nature 361, 721-724.

Davenport RW \& Kater SB (1992). Local increases in intracellular calcium elicit local filopodial responses in Helisoma neuronal growth cones. Neuron 9, 405-416.

Davidkova G, Zhang SP, Nichols RA \& Weiss B (1996) Reduced level of calmodulin in PC12 cells induced by stable expression of calmodulin antisense RNA inhibits cell proliferation and induces neurite outgrowth. Neuroscience 75, 1003-1019.

De Bernardi MA, Rabins SJ, Colangelo AM, Brooker G \& Mocchetti I (1996) TrkA mediates the nerve growth factor-induced intracellular calcium accumulation. J Biol Chem 271, 6092-6098.

Deisseroth K, Bito H \& Tsien RW (1996) Signaling from synapse to nucleus: postsynaptic CREB phosphorylation during multiple forms of hippocampal synaptic plasticity. Neuron 16, 89-101.

Desarmenien MG, Clendening B \& Spitzer NC (1993) In vivo development of voltage-dependent ionic currents in embryonic xenopus spinal neurons. J Neurosci 13, 2575-2581.

Desarmenien MG \& Spitzer NC (1991) Role of calcium and protein kinase C in development of the delayed rectifier potassium current in xenopus spinal neurons. Neuron 7, 797-805.

Doherty P, Fazeli MS \& Walsh FS (1995) The neural cell adhesion molecule and synaptic plasticity. J Neurobiol 26, 437-446.

Doherty P, Furness J, Williams EJ \& Walsh FS (1994) Neurite outgrowth stimulated by the tyrosine kinase inhibitor herbimycin A requires activation of tyrosine kinases and protein kinase C. J Neurochem 62, 2124-2131.

Doherty P, Singh A, Rimon G, Bolsover SR \& Walsh FS (1993) Thy-1 antibody triggered neurite outgrowth requires an influx of calcium into neurons via $\mathrm{N}$ and $\mathrm{L}$ type calcium channels. J Cell Biol 122, 181-189.

Doherty P \& Walsh FS (1996) CAM-FGF receptor interactions: A model for axonal growth. Mol Cell Neurosci 8, 99-111.

Doherty P \& Walsh FS (1994) Signal transduction events underlying neurite outgrowth stimulated by cell adhesion molecules. Curr Opin Neurobiol 4, 49-55. 
Erskine L Stewart R \& McCaig CD (1995) Electric field-directed growth and branching of cultured frog nerves: effects of aminoglycosides and polycations. J Neurobiol 26, 523-536.

Ferreira A, Kincaid R \& Kosik KS (1993) Calcineurin is associated with the cytoskeleton of cultured neurons and has a role in the acquisition of polarity. Mol Biol Cell 4, 1225-1238.

Fields RD, Guthrie PB, Russell JT, Kater SB, Malhotra BS \& Nelson PG (1993) Accommodation of mouse DRG growth cones to electrically induced collapse: kinetic analysis of calcium transients and set-point theory. $J$ Neurobiol 24, 1080-1098.

Fields RD, Neale EA \& Nelson PG (1990) Effects of patterned electrical activity on neurite outgrowth from mouse sensory neurons. J Neurosci 10, 2950-2964.

Fields RD \& Nelson PG (1994) Resonant activation of calcium signal transduction in neurons. J Neurobiol 25, 281-93.

Finkbeiner S \& Greenberg ME (1996) $\mathrm{Ca}^{2+}$-dependent routes to Ras: mechanisms for neuronal survival, differentiation, and plasticity? Neuron 16, 233-236.

Futerman AH \& Banker GA (1996) The economics of neurite outgrowth-the addition of new membrane to growing axons. Trends Neurosci 19, 144-149.

Galione A (1992) $\mathrm{Ca}^{2+}$-induced $\mathrm{Ca}^{2+}$ release and its modulation by cyclic ADP-ribose. Trends Pharmacol Sci 13, 304-306.

Gallin WJ \& Greenberg ME (1995) Calcium regulation of gene expression in neurons: the mode of entry matters. Curr Opin Neurobiol 5, 367-374.

Gallo G, Lefcort FB \& Letourneau PC (1997) The trkA receptor mediates growth cone turning toward a localized source of nerve growth factor. $J$ Neurosci 17, 5445-5454.

Ghosh A, Carnahan J \& Greenberg ME (1994) Requirement for BDNF in activity-dependent survival of cortical neurons. Science 263, 1618-1623.

Ginty DD (1997) Calcium regulation of gene expression: isn't that spatial? Neuron 18, 183-186.

Gomez TM, Snow DM \& Letourneau PC (1995) Characterization of spontaneous calcium transients in nerve growth cones and their effect on growth cone migration. Neuron 14, 1233-46.

Goshima Y, Ohsaka S \& Yamauchi T (1993) Overexpression of calcium/calmodulin dependent protein kinase II in neuro 2a and NG108-15 neuroblastoma cell line promotes neurite outgrowth and growth cone motility. $J$ Neurosci 13, 559-567.

Gottmann K \& Lux HD (1995) Growth cone calcium ion channels: properties, clustering, and functional roles. Perspect Dev Neurobiol 2, 371-377.

Grunz H (1997) Neural Induction in Amphibians. Current Topics in Developmental Biology 35, 191-228.

Gu X, Olson E \& Spitzer NC (1994) Spontaneous neuronal calcium spikes and waves during early differentiation. J Neurosci 14, 6325-6335.

$\mathrm{Gu}$ X \& Spitzer NC (1995) Distinct aspects of neuronal differentation encoded by frequency of spontaneous $\mathrm{Ca}^{2+}$ transients. Nature $375,785-787$.

Gu X \& Spitzer NC (1997) Breaking the code: regulation of neuronal differentiation by spontaneous calcium transients. Dev Neurosci 19, 33-41.

Guerini D (1997) Calcineurin: not just a simple protein phosphatase. Biochem Biophys Res Commun 235, 271-275.

Gundersen RW \& Barrett JN (1980) Characterization of the turning response of dorsal root neurites toward nerve growth factor. J Cell Biol 87, 546-54.

Hanson IH \& Schulman H (1992) Neuronal $\mathrm{Ca}^{2+} /$ calmodulin-dependent protein kinases. Ann Rev Biochem 61, 559-601.

Harper SJ, Bolsover SR, Walsh FS \& Doherty P (1994) Neurite outgrowth stimulated by L1 requires calcium influx into neurons but is not associated with changes in steady state levels of calcium in growth cones. Cell Adhesion and Communication 2, 441-453.

Hatten ME (1993) The role of migration in central nervous system neuronal development. Curr Opin Neurobiol 3, 38-44.

Haydon PG, McCobb DP \& Kater SB (1984) Serotonin selectively inhibits growth cone motility and synaptogenesis of specific identified neurons. Science 226, 561-564.

Holliday J, Adams RJ, Sejnowski TJ \& Spitzer NC (1991) Calcium-induced release of calcium regulates differentiation of cultured spinal neurons. Neuron 7, 787-796.

Holliday J \& Spitzer NC (1990) Spontaneous calcium influx and its role on differentiation of spinal neurons in culture. Dev Biol 141, 13-23.

Igarashi M, Kozaki S, Terakawa S, Kawano S, Ide C \& Komiya Y (1996) Growth cone collapse and inhibtion of neurite growth by Botulinum neurotoxin $\mathrm{C} 1$ : a t-SNARE is involved in axonal growth. $J$ Cell Biol 134, 205-215. 
Igarashi M, Strittmatter SM, Vartanian T \& Fishman MC (1993) Mediation by G proteins of signals that cause collapse of growth cones. Science 259, 77-79.

Ignelzi MA Jr, Miller DR, Soriano P \& Maness PF (1994) Impaired neurite outgrowth of src-minus cerebellar neurons on the cell adhesion molecule L1. Neuron 12, 873-84.

Ishida I. \& Deguchi T (1983) Effect of depolarizing agents on choline acetyltransfersae and acetylcholinestaerase activites in primary cell cultures of spinal cord. $J$ Neurosci $3,1818-1823$.

Ivins JK, Raper JA \& Pittman RN (1991) Intracellular calcium levels do not change during contact-mediated collapse of chick DRG growth cone structure. J Neurosci 11, 1597-1608.

Jaffe LF \& Poo MM (1979) Neurites grow faster towards the cathode than the anode in a steady field. $J$ Exp Zool 209, 115-128.

Janmey PA (1994) Phosphoinositides and calcium as regulators of cellular actin assembly and disassembly. Annu Rev Physiol 56, 169-191.

Jia WG, Beaulieu C, Liu YL \& Cynader M (1992) Calcium calmodulin dependent kinase II in cat visual cortex ' and its development. Dev Neurosci 14, 238-246.

Johnson CM, Hill CS, Chawla S, Treisman R \& Bading H (1997) Calcium controls gene expression via three distinct pathways that can function independently of the Ras/mitogen-activated protein kinases (ERKs) signaling cascade. J Neurosci 17, 6189-6202.

Kater SB, Mattson MP, Cohan C \& Connor J (1988) Calcium regulation of the neuronal growth cone.Trends Neurosci 11, 315-321.

Kater SB \& Mills LR (1991) Regulation of growth cone behavior by calcium. J Neurosci 11, 891-899.

Klee CB, Guerini D, Krinks MH, De Camilli P \& Solinema M (1990) Calcineurin : A major $\mathrm{Ca}^{2+} /$ calmodulinregulated protein phosphatase in brain.: Raven Press, Washington DC.

Klostermann S \& Bonhoeffer F (1996) Investigations of signaling pathways in axon growth and guidance.Perspect Dev Neurobiol 4, 237-252.

Komuro H \& Rakic P (1996) Intracellular $\mathrm{Ca}^{2+}$ fluctuations modulate the rate of neuronal migration. Neuron 17, 275-285.

Komuro H \& Rakic P (1993) Modulation of neuronal migration by NMDA receptors. Science 260, 95-97.

Komuro H \& Rakic P (1992) Selective role of N-type calcium channels in neuronal migration. Science 257, 806-809.

Kuhn TB Schmidt MF \& Kater SB (1995) Laminin and fibronectin guideposts signal sustained but opposite effects to passing growth cones. Neuron 14, 275-285.

Lander AD (1989) Understanding the molecules of neural cell contacts: emerging patterns of structure and function. Trends Neurosci 12, 189-195.

Lankford K, Cypher C \& Letourneau P (1990) Nerve growth cone motility. Curr Opin Cell Biol 2, 80-85.

Lankford KL, \& Letourneau PC (1989) Evidence that calcium may control neurite outgrowth by regulating the stability of actin filaments. $J$ Cell Biol 109, 1229-1243.

Lankford KL \& Letourneau PC (1991) Roles of actin filaments and three second-messenger systems in short-term regulation of chick dorsal root ganglion neurite outgrowth. Cell Motil Cytoskeleton 20, 7-29.

Leclerc C, Daguzan C, Nicolas M-T, Chabret C, Duprat A-M \& Moreau M (1997) L-type calcium channel activation controls the in vivo transduction of the neuralising signal in the amphibian embryos. Mech Dev 64, 105-110.

Letourneau PC (1983) Differences in the organization of actin in the growth cones compared with the neurites of cultured neurons from chick embryos. J Cell Biol 97, 963-973.

Leveque C, El Far O, Martin-Moutot N, Sato K, Kato R, Takahashi M \& Seagar MJ (1994) Purification of the Ntype calcium channel associated with syntaxin and synaptotagamin. J Biol Chem 269, 6306-6312.

Li M, Jia M, Fields RD \& Nelson PG (1996) Modulation of calcium currents by electrical activity. J Neurophysiol 76, 2595-2607.

Liesi P \& Wright JM (1996) Weaver granule neurons are rescued by calcium channel antagonists and antibodies against a neurite outgrowth domain of the B2 chain of laminin. J Cell Biol 134, 477-486.

Lipfert L, Haimovich B, Schaller MD, Cobb BS, Parsons JT \& Brugge JS (1992) Integrin-dependent phosphorylation and activation of the protein tyrosine kinase pp125FAK in platelets. J Cell Biol 119, 905-912.

Lipscombe D, Madison DV, Poenie M, Reuter H, Tsien RY, \& Tsien RW (1988) Spatial distribution of calcium channels and cytosolic calcium transients in growth cones and cell bodies of sympathetic neurons. Proc Natl Acad Sci USA 85, 2398-2402.

Liu JP (1996) Protein kinase C and its substrates. Mol Cell Endocrinol 116, 1-29.

Lockerbie RO, Miller VE \& Pfenninger KH (1991) Regulated plasmalemmal expansion in nerve growth cones. $J$ Cell Biol 112, 1215-1227. 
Loschinger J, Bandtlow CE, Jung J, Klostermann S, Schwab ME, Bonhoeffer F \& Kater SB (1997) Retinal axon growth cone responses to different environmental cues are mediated by different second-messenger systems. J. Neurobiol 33, 825-834.

Matthews G (1996) Neurotransmitter release. Ann Rev Neurosci 19, 219-233.

Mattson MP, Taylor Hunter A \& Kater SB (1988) Neurite outgrowth in individual neurons of a neuronal population is differentially regulated by calcium and cyclic AMP. $J$ Neurosci 8, 1704-1711.

McCaig CD \& Erskine L (1996) Nerve growth and nerve guidance in a physiological electric field. In Nerve Growth and Guidance, C. D. McCaig, ed. (London: Portland Press Ltd), pp. 150-170.

Mehler MF, Mabie PC, Zhang D \& Kessler JA (1997) Bone morphogenetic proteins in the nervous system. Trends Neurosci 20, 309-317.

Mills LR \& Kater SB (1990) Neuron-specific and state-specific differences in calcium homeostasis regulate the generation and degeneration of neuronal architecture. Neuron 4, 149-163.

Moorman SJ \& Hume RI (1994) Locus coeruleus neuron growth cones and spinal cord regeneration. Brain Res Bull 35, 419-422.

Moreau M, Leclerc C, Gualandris-Parisot L \& Duprat A-M (1994) Increased internal $\mathrm{Ca}^{2+}$ mediates neural induction in the amphibian embryo. Proc Natl Acad Sci USA 91, 12639-12643.

Murrain M, Murphy AD, Mills LR \& Kater SB (1990) Neuron-specific modulation by serotonin of regenerative outgrowth and intracellular calcium within the CNS of Helisoma trivolvis. J Neurobiol 21, 611-618.

Nairn AC \& Picciotti MR (1994) Calcium/calmodulin-dependent protein kinases. Semin Cancer Biol 5, 295-303.

Niki I, Yokokura H, Sudo T, Kato M \& Hidaka $\mathrm{H}(1996) \mathrm{Ca}^{2+}$ signaling and intracellular $\mathrm{Ca}^{2+}$ binding proteins. $J$ Biochem Tokyo 120, 685-98.

Nomura T, Kumatoriya K, Yoshimura Y \& Yamauchi T (1997) Overexpression of alpha and beta isoforms of $\mathrm{Ca}^{2+} /$ calmodulin-dependent protein kinase II in neuroblastoma cells- H-7 promotes neurite outgrowth. Brain Res 766, 129-141.

Osen-Sand A, Catsicas M, Staple JK, Jones KA, Ayala G, Knowles J, Grenningloh G \& Catsicas S (1993) Inhibition of axonal growth by SNAP-25 antisense oligonucleotides in vitro and in vivo. Nature 364, 445-448.

Oyler GA, Polli JW, Wilson MC \& Billingsey ML (1991) Developmental expression of the 25-kDa synaptosomalassociated protein. Proc Natl Acad Sci USA 88, 5247-5251.

Pate Skene JH (1990) GAP-43 as a "calmodulin sponge" and some implications for calcium signalling in axon terminals. Neurosci Res Suppl. 13, S112-S125.

Picciotto MR, Nastiuk KL \& Nairn AC (1996) Structure, regulation and function of calcium/calmodulin-dependent protein kinase I. Adv Pharmacol 36, 251-275.

Qian J, Wang HY, Fischer I, Friedman E \& Levitt P (1994) Involvement of protein kinase C in the axonal growthpromoting effect on spinal cord neurons by target-derived astrocytes. J Neurobiol 25, 1593-1612.

Rakic P \& Komuro H (1995) The Role of Receptor/Channel Activity in Neuronal Cell Migration. J Neurobiol 26, 299-315.

Rakic P, Cameron RS \& Kumoro H (1994) Recognition, adhesion, transmembrane signalling and cell motility in guided neuronal migration. Curr Opin Neurobiol 4, 63-69.

Rakic P, Knyihar-Csilik E \& Csillik B (1996) Polarity of microtubule assembilies during neuronal migration. Proc Natl Acad Sci USA 93, 9218-9222.

Ramon y Cajal S (1890) Sur l'origine et les ramifications des fibres nerveuses de la moelle embryonaire. Anatomischer Anzeiger 5, 609-613.

Rehder V, Williams CV \& Kater SB (1996) Functional compartmentalization of the neuronal growth cone: determining calcium's place in signaling cascades. Perspect Dev Neurobiol 4, 215-226.

Rosen LB, Ginty DD, Weber MJ \& Greenberg ME (1994) Membrane depolarization and calcium influx stimulate MEK and MAP kinase via activation of Ras. Neuron 12, 1207-1221.

Sakagami H \& Kondo H (1993) Differential expression of mRNAs encoding gamma and delta subunits of $\mathrm{Ca}^{2+} /$ calmodulin-dependent protein kinase type II (CaM kinase II) in the Mature and Postnatally Developing Rat Brain. Brain Res Mol Brain Res 20, 51-63.

Sakagami H, Tsubochi H \& Kondo H (1994) Immunohistochemical localisation of $\mathrm{Ca}^{2+} /$ calmodulin-dependent protein kinase IV in the peripheral ganglia and paraganglia of developing and mature rats. Brain Res 666 , 173-181.

Sakagami H, Watanabe M \& Kondo H (1992) Gene expression of $\mathrm{Ca}^{2+} /$ calmodulin-dependent protein kinase of the cerebellar granule type or type IV in the mature and developing rat brain. Brain Res Mol Brain Res 16, 20-28.

Sawamura Y, Sakagami H \& Kondo H (1996) Localisation of mRNA for $\mathrm{Ca}^{2+} /$ calmodulin-dependent protein kinase $\mathrm{I}$ in the brain of developing and mature rats. Brain Res 706, 259-266. 
Schaad NC, De Castro E, Nef S, Hegi S, Hinrichsen R, Martone ME, Ellisman MH, Sikkink R, Rusnak F, Sygush J \& Nef P (1996) Direct modulation of calmodulin targets by the neuronal calcium sensor NCS-1. Proc Natl Acad Sci USA 93, 9253-9258.

Schaller MD, Hildebrand JD, Shannon JD, Fox JW, Vines RR \& Parsons JT (1994) Autophosphorylation of the focal adhesion kinase, pp125FAK, directs SH2-dependent binding of pp60src. Mol Cell Biol 14, 1680-1688.

Schuch U, Lohse MJ \& Schachner M (1989) Neural cell adhesion molecules influence second messenger systems. Neuron 3, 13-20.

Schwab ME (1990) Myelin-associated inhibitors of neurite growth and regeneration in the CNS. Trends Neurosci $13,452-456$.

Segal RA \& Greenberg ME (1996) Intracellular signaling pathways activated by neurotrophic factors. Annu Rev Neurosci 19, 463-489.

Seger R \& Krebs EG (1995) The MAPK signaling cascade. FASEB J 9, 726-735.

Serafini T, Kennedy TE, Galko MJ, Mirzayan C, Jessell TM \& Tessier Lavigne M (1994) The netrins define a family of axon outgrowth-promoting proteins homologous to C. elegans UNC-6. Cell 78, 409-424.

Sheng Z-H, Rettig J, Cook T \& Catterall WA (1996) Calcium-dependent interaction of N-type calcium channels with the synaptic core complex. Nature 379, 451-454.

Sheng Z-H, Rettig J, Takahashi M \& Catterall WA (1994) Identification of a Syntaxin-Binding Site on N-Type Calcium Channels. Neuron 13, 1303-1313.

Silver RA, Lamb AG \& Bolsover SR (1990) Calcium hotspots caused by L-channel clustering promote morphological changes in neuronal growth cones. Nature $343,751-754$.

Soderling (1996) Structure and regulation of calcium/camodulin-dependent protein kinases II and IV. Biochim Biophys Acta 1297, 131-138.

Spitzer NC (1991) A Developmental Handshake: Neuronal Control of Ionic Currents and Their Control of Neuronal Differentiation. J Neurobiol 22, 659-673.

Spitzer NC (1994) Spontaneous calcium spikes and waves in embryonic neurons: signalling systems for differentiation. Trends Neurosci 17, 115-118.

Spitzer NC, Debaca RC, Allen KA \& Holliday J (1993) Calcium dependence of differentiation of GABA immunoreactivity in spinal neurons. J Comp Neurol 337, 168-175.

Stewart R, Erskine L \& McCaig CD (1995) Calcium channel subtypes and intracellular calcium stores modulate electric field-stimulated and-oriented nerve growth. Dev Biol 171, 340-351.

Tanaka C \& Nishizuka Y (1994) The protein kinase C family for neuronal signaling. Annu Rev Neurosci 17, 551-567.

Theodore L, Derossi D, Chassaing G, Llirbat B, Kubes M, Jordan P, Chneiweiss H, Godement P \& Prochiantz A (1995) Intraneuronal delivery of protein kinase $C$ pseudosubstrate leads to growth cone collapse. J Neurosci $15,7158-7167$.

Tint IS, Bonder EM, Feder HH, Reboulleau CP, Vasiliev JM \& Gelfand IM (1992) Reversible structural alterations of undifferentiated and differentiated human neuroblastoma cells induced by phorbol ester. Proc Natl Acad Sci USA 89, 8160-8164.

Torreano PJ \& Cohan CS (1997) Electrically induced changes in $\mathrm{Ca}^{2+}$ in Helisoma neurons: regional and neuronspecific differences and implications for neurite outgrowth. J Neurobiol 32, 150-162.

Vanberkum MF (1996) Signal transduction during axon guidance: a genetic analysis in drosophila. Perspectives in Dev Neurobiol 4, 227-236.

VanBerkum MF \& Goodman CS (1995) Targeted disruption of $\mathrm{Ca}^{2+}$-calmodulin signaling in Drosophila growth cones leads to stalls in axon extension and errors in axon guidance. Neuron 14, 43-56.

Vigers AJ \& Pfenninger KH (1991) N type and L type calcium channels are present in nerve growth cones. Numbers increase on synaptogenesis. Dev Brain Res 60, 197-203.

Vogt L, Giger RJ, Ziegler U, Kunz B, Buchstaller A, Hermens W, Kaplitt MG, Rosenfeld MR, Pfaff DW, Verhaagen J \& Sonderegger P (1996) Continuous renewal of the axonal pathway sensor apparatus by insertion of new sensor molecules into the growth cone membrane. Curr Biol 6, 1153-1158.

von Bohlen und Halbach F, Taylor J \& Schachner M (1992) Cell type-specific effects of the neural adhesion molecules L1 and N-CAM on diverse second messenger systems. Eur J Neurosci 4, 896-909.

Walicke P, Campenot R \& Patterson P (1977) Determination of Transmitter Function by Neuronal Activity. Proc Natl Acad Sci USA 74, 5767-5771.

Walicke PA \& Patterson PH (1981) On the role of Ca in the transmitter choice made by cultured sympathetic neurons. J Neurosci 1, 343-350.

Williams CV, Kuhn TB, Dou P \& Kater SB (1995) Dual function of calcium in laminin-mediated growth cone guidance: 1. Early calcium signal in filopodia underlies growth cone turning. Soc Neurosci Abstracts 21, 594. 
Williams EJ, Doherty P, Turner G, Reid RA, Hemperly JJ \& Walsh FS (1992) Calcium influx into neurons can solely account for cell contact-dependent neurite outgrowth stimulated by transfected L1. J Cell Biol 119, 883-892.

Williams EJ, Mittal B, Walsh FS \& Doherty P (1995) A Ca ${ }^{2+} /$ calmodulin kinase inhibitor, $\mathrm{KN}-62$, inhibits neurite outgrowth stimulated by CAMs and FGF. Mol Cell Neurosci 6, 69-79.

Wilson PA \& Hemmati-Brivanlou A (1997) Vertebrate neural induction: inducers, inhibitors, and a new synthesis. Neuron 18, 699-710.

Zheng F, Gallagher JP \& Connor JA (1996) Activation of a metabotropic excitatory amino acid receptor potentiates spike-driven calcium increases in neurons of the dorsolateral septum. J Neurosci 16, 6079-6088.

Zheng JQ, Felder M, Connor JA \& Poo MM (1994) Turning of nerve growth cones induced by neurotransmitters. Nature 368, 140-144.

Zimprich F \& Bolsover SR (1996) Calcium channels in neuroblastoma cell growth cones. Eur J Neurosci 8, 467-475.

Zucker RS (1996) Exocytosis: a molecular and physiological perspective. Neuron 17, 1049-1055. 